ARTIGOS - ARTICLES

\title{
A participação italiana nas primeiras décadas do movimento americanista (1890-1946)
}

\author{
Andrea Ciacchi ${ }^{1}$ \\ Professor do Departamento de História \\ Universidade Federal da Integração Latino-Americana de Foz do Iguaçu \\ andrea.ciacchi@unila.edu.br
}

\begin{abstract}
Como citar este artigo: CIACCHI, A. "A participação italiana nas primeiras décadas do movimento americanista (1890-1946)", Intelligere, Revista de História Intelectual, nº 7 , p. 1-52. 2019. Disponível em $<$ http://revistas.usp.br/revistaintelligere $>$. Acesso em dd/mm/aaaa.
\end{abstract}

Resumo: Este artigo aborda a participação italiana no "movimento americanista", considerado desde a criação, em 1895, da Société Américaniste de Paris $(S A P)$, e num recorte cronológico que se encerra no final da II Guerra Mundial. Através da reconstrução das trajetórias de alguns nomes que se ligaram a esse campo, busca-se compreender o alcance e a consistência da contribuição italiana aos estudos americanos, no período selecionado.

Palavras-chave: Americanística, Intelectuais italianos, América Latina, Antropologia, Etnologia.

Italian participation in the first decades of the Americanist movement (1890-1946).

Abstract: This paper deals with Italian participation in the "Americanist movement", considered since the creation in 1895 of the Société Américaniste de Paris (SAP), and in a chronological cut that ends at the end of World War II. Through the reconstruction of the trajectories of some names that have been linked to this field, it is sought to understand the reach and consistency of the Italian contribution to the American studies in the selected period.

Keywords: Americanism, Italian Scholars, Latin America, Anthropology, Ethnology.

1 Andrea Ciacchi, antropólogo pela Universidade de Roma La Sapienza (1984), mestre em Literatura Brasileira pela UFPB (1988) e doutor em Estudos Ibéricos pela Universidade de Bolonha (1993), é docente da Universidade Federal da Integração Latino-Americana, onde desenvolve pesquisas na área da história intelectual latino-americana. andrea.ciacchi@unila.edu.br 


\section{Introdução}

São muito conhecidas as dinâmicas da institucionalização da americanística francesa, em finais do século XIX. Como lembra Vélez (2007: 338), houve uma passagem de bastão, entre a Société Américaine de France ( $S A F)$, criada em 1874 e que se fundiu à Société d'Ethnologie em 1893, e a Société des Americanistes de Paris (SAP), surgida em 1895 tendo por promotores, sob a batuta de Ernest Hami (Laurière, 2009b), quase todos os mesmos intelectuais e as mesmas personalidades (políticas, diplomáticas, econômicas) que haviam dado vida à $S A F$. Ao longo dessa transição, que teve portanto pouco mais de duas décadas de duração, celebraram-se os primeiros onze "Congressos Internacionais dos Americanistas", desde o de 1875, em Nancy, até o realizado na Cidade do México em 1895 - que foi o primeiro fora do continente europeu $^{2}$ (em ritmo bienal, os demais foram sediados em Luxemburgo, Bruxelas, Madrid, Copenhague, Turim³ , Berlim, Paris, Huelva e Estocolmo). Os congressos, de acordo com Vélez (ibidem) foram "vías de difusión del americanismo en los siglos XIX y XX, además de plataformas de actuación, de compromisso político y de sociabilidade", nos quais se encontravam "eruditos, viajeros-aventureros, colecionistas al estilo 'ilustrado', geógrafos y políticos" (ibidem). Em volta desses encontros e das atividades da Société des Americanistes se entrecruzavam e se articulavam inflexões ideológicas diversas, tanto no contexto, especificamente francês, das sociétés savantes as quais ainda perfaziam uma tradição intelectual que remontava ao século XVII, mas que se notabilizou naquele país sobretudo desde a segunda metade do século XVIII até todo o XIX, quanto no pano de fundo dos interesses geopolíticos e econômicos de uma das mais proeminentes potências coloniais do cenário internacional.

O contexto da França nesse final do século XIX, quando a Société des Americanistes de Paris vê a luz, também é bem conhecido. Estamos no meio da "Terceira República" (1870-1914) e no começo de um período de robusto crescimento econômico do país, que, por sua vez, se inseria naquilo que a historiografia francesa considera o "segundo império colonial francês", ao

\footnotetext{
2 Para uma historiografia bastante detalhada dos Congressos, até os anos cinquenta do século XX, veja Comas (1974).

${ }^{3}$ Só no caso do Congresso realizado na Itália (1886), o intervalo com relação ao anterior foi de três anos. Cf. Comas (1974).
} 
longo do qual se consolidou notadamente a presença da França na África setentrional e ocidental, e também no Madagascar, no sudeste asiático (a chamada Indochine française, incluindo os atuais Vietnam, Camboja e Laos) e na Oceania (Nova Caledônia e Polinésia Francesa). Nas Américas, a presença francesa se limitava a Guadalupe e Martinica, no Caribe, e à Guiana, na América do Sul, de forma que um empreendimento "americanista" podia mais facilmente se apresentar como exclusivamente intelectual e científico, sem ligações aparentes e diretas com o colonialismo ou mesmo a política exterior do país ${ }^{4}$.

Pretendo inserir nessa história atores pouco ou pouquíssimo mencionados: intelectuais italianos que, em formas e momentos diferentes, participaram direta ou indiretamente do "movimento americanista", tanto em funções institucionais reconhecidas (a partir de museus, universidades, sociedades científicas etc.), como em outras modalidades (missionários, aventureiros, exploradores, diplomatas etc.). Além disso, imagino este trabalho como propedêutico à articulação de possíveis respostas para algumas questões também pouco frequentes na literatura relativa à história intelectual italiana e latino-americana. De fato, parece-me que ainda mereçam respostas (ou a reconstrução de fatos e trajetórias que encaminhem hipóteses de respostas) perguntas como: existiu uma "americanística italiana"? Quais as suas características, se houver, peculiares? Como ela se diferencia, se se diferencia, da francesa? Qual o seu processo de construção e institucionalização (trajetórias, instituições, revistas, publicações, viagens)? Qual o seu papel no processo de conformação da antropologia social e cultural italiana do século $\mathrm{XX} ?^{5}$ De fato, se por um lado parece haver consenso em volta do

\footnotetext{
${ }^{4}$ Não está nos objetivos nem nas possibilidades deste trabalho investigar ou mesmo comentar as relações entre a institucionalização do americanismo francês e as necessidades ideológicas daquela potência colonial nesse quadrante histórico de entresséculos. Análises e reconstruções parciais, mas que constituem excelentes pontos de partida encontram-se em Laurière (2009b), Prévost Urkidi (2009) e Riviale (1995).

${ }^{5}$ Este trabalho surgiu de uma permanência na Itália na qual se desenvolveu um projeto de pósdoutorado intitulado "Objetos etnográficos e ideias antropológicas", voltado à elucidação das relações intelectuais entre Itália e América do Sul, num período compreendido entre meados do século XIX e meados do XX, com ênfase nos trabalhos e nas trajetórias intelectuais que lidaram com as várias formas da alteridade latino-americana. Agradeço aqui as pessoas que possibilitaram acesso a obras raras e não digitalizadas que foram fundamentais para a redação deste trabalho: Marco Ramírez Mercado, em Guadalajara, e Onofrio Pappagallo, do Instituto Italo-Latinoamericano (IILA) de Roma.
} 
reconhecimento de que uma americanística italiana existiu, sim, na medida em que houve olhares italianos voltados para observações de natureza etnográfica (aí incluindo a atuação também de geógrafos, linguistas, antropólogos físicos, arqueólogos, paleontólogos, historiadores, além de outros "eruditos" não necessariamente catalogáveis disciplinarmente) que permitem a incorporação à história das ideias latino-americanas dessas contribuições, por outro, porém, não encontro trabalhos que, mais organizadamente (ou seja, para além da reconstrução de trajetórias individuais desse ou desse outro intelectual), permitam uma apreensão mais inteiriça de um fenômeno que, inclusive, traz consequências até os dias de hoje ${ }^{6}$.

Como se sabe, no início do período que aqui se considera, ou seja, contemporaneamente ao começo da institucionalização da americanística francesa, o colonialismo italiano também passava muito longe das Américas. Apenas como informação contextualizadora, vale lembrar que a Itália ocupou e dominou a Eritreia (de 1882 a 1947) e a Somália (de 1890 a 1960). Mais tarde e por período muito mais curtos, a Itália ainda ocuparia a Líbia (1911-1943) e a Etiópia (1936-1941). Por outro lado, porém, e agora apenas mencionando um tema extremamente bem estudado por várias historiografias nacionais, a presença de imigrantes italianos em quase todos os países das Américas, consequência e causa de vários e complexos processos sociais, econômicos e culturais, é, sim, um pano de fundo muito relevante para uma investigação em volta da americanística italiana e, mais em geral, das relações intelectuais e científicas entre a Itália e as Américas. Como veremos, alguns dos nomes que protagonizam ou atravessam fases do campo americanista italiano estão de alguma forma ligados a esses processos. Encontram-se casos de "cientistas" recrutados na América entre as primeiras ou segundas gerações de migrantes, casos de personagens italianos que, a vário título, "exploram" aspectos da América (sobretudo a "latina") com o intuito de acelerar, incrementar e desenvolver a ação de agentes econômicos italianos em algumas regiões, e,

6 O panorama contemporâneo dos estudos "americanos" na Itália (com o sem sinônimos, prefixos ou sufixos) é extremamente variegado e dinâmico. Eles compreendem e atravessam campos diferentes, em arranjos institucionais que obedecem a critérios frequentemente determinados por histórias acadêmicas locais, sendo que as suas atividades se desenvolvem quase exclusivamente a partir de sedes universitárias. Trata-se, infelizmente, de outro tema (ou sugestão de pesquisa) que não posso sequer esboçar aqui. Um ponto de partida se encontra em alguns capítulos de Alliegro (2011). 
também, casos de intelectuais italianos, institucionalmente radicados e ativos na Itália, em vários campos disciplinares e possuidores de diferentes capitais simbólicos, que se apoiam em grupos ou organizações de italianos nas Américas para desenvolverem atividades, de maior ou menor duração e intensidade, naqueles territórios.

Por outro lado, finalmente, também cabe lembrar que a Itália, cuja soberania nacional datava apenas de 1861, se encontrava, nesse final de século, governada pelo que a historiografia italiana denomina "esquerda histórica", que, inclusive com viés autoritário, tentou administrar um período de grandes convulsões sociais, que acabaram culminando, em 1900, com o assassinato do rei Umberto I por um militante anarquista. Com a chegada do século XX, depois da entronização do filho de Umberto, Vittorio Emanuele III, a elite nacional buscou promover a modernização do estado liberal. Nesse contexto de fortes mudanças econômicas e sociais, consolidou-se um ambiente filosófico e cultural de marca positivista, também como expressão de uma cultura laica e devedora dos valores da burguesia em ascensão, no bojo do qual se promoveu o "espírito científico", adotando ou proclamando a adoção dos métodos "positivos" ou "experimentais" no estudo do homem, em todas as suas vertentes e em todos os seus aspectos, não só como homme physique, mas, também, como homme morale, tentando ultrapassar, assim, a especulação apenas filosófica. Localiza-se aí o surgimento das "ciências humanas", identificadas principalmente na sociologia, na antropologia (ou "etnologia"), na criminologia, na psicologia e pedagogia, em empreendimentos fronteiriços com a medicina (pelo viés da higiene, mas também das "contaminações" com anatomia, morfologia e antropologia física) e a geografia. Essas, almejando alcançar um estatuto científico equivalente ao das ciências físicas e naturais, aumentaram os seus espaços institucionais. Dessa forma, como veremos, aos eruditos e/ou aos especialistas das várias disciplinas abriam-se possibilidades novas, como a multiplicação de sociedades científicas e de revistas, além da intensificação do labor acadêmico, inclusive com a criação de novas cátedras universitárias ${ }^{7}$. Um dos aspectos dessa renovação da vida cultural e intelectual

\footnotetext{
${ }^{7}$ Não sendo possível indicar percursos bibliográficos exaustivos para o conjunto das questões abordadas nesse parágrafo, limito-me a sugerir a leitura de trabalhos de cunho mais geral, como Candeloro (1968, 1970 e 1974), Micheli (1980), Vivanti (1981), Cimino e Lombardo
} 
italiana, no período que vai da unificação nacional à virada do século XX (ou seja, no percurso entre o romantismo e o positivismo) é o que permitiu uma reaproximação entre a cultura italiana e a europeia, nomeadamente a francesa e a alemã, tendo como efeito colateral uma série de tentativas de "desprovincialização", incluindo investidas contra as velhas retóricas nacionalistas, os formalismos e os reacionarismos (Candeloro, 1968). Será nesse quadro, finalmente, que se afirmará a adesão de alguns intelectuais italianos ao darwinismo (Landucci, 1977).

Numa visada ainda mais geral, vê-se que na Itália não se determina um clima intelectual muito diferente do que vinha sendo construído em outros países, compartilhando, aliás, tendências, estilos, idiossincrasias. Entretanto, parece-me que no caso italiano isso estava mais claramente inserido num contexto de nation building que, por exemplo, não se podia aplicar à França ou à Espanha, o que poderia gerar, evidentemente, novas sugestões de pesquisa. Só para apontar um viés implícito nessa hipótese, creio que se deva considerar a relação, que tão frequentemente aparecerá, sobretudo nas décadas iniciais da americanística italiana, entre as biografias de muitos intelectuais atraídos pelas culturas americanas e o ideário do Risorgimento ${ }^{8}$, de algumas etapas do qual alguns deles participaram, e no qual se entrecruzavam anseios independentistas, mas, também, socialistas e/ou republicanos. Não será nem um pouco casual o "peso", historiográfico e simbólico de um personagem como Giuseppe Garibaldi, protagonista absoluto desse quadrante da vida político-social italiana e objeto de fortes disputas ideológicas, sobretudo em volta da sua "herança" simbólica ${ }^{9}$. Como veremos, porém, um outro mito capaz de constituir uma imagem retórica de "ponte" entre a Itália e a América é o do navegador

(2014), Russo e Santoni (2010), De Liguori (1988 e 1990), Chiarelli e Pasini (2010), Landucci (1987).

8 Termo utilizado tanto pelos seus protagonistas quanto pela historiografia sucessiva, para indicar o período da história italiana em que se desenvolveu o processo de unificação nacional, incluindo os seus aspectos militares, políticos, diplomáticos, sociais e culturais.

${ }^{9} \mathrm{O}$ fato de Garibaldi ter recebido a alcunha de eroe dei due mondi sinaliza, justamente nos "dois mundos", a Itália e a América (latina, mas não só), os efeitos relacionais da construção e da reprodução de um "mito" cujas repercussões no âmbito intelectual ainda podem render novas contribuições. A bibliografia sobre essas questões é muito ampla: na historiografia italiana (atravessada desde o começo por disputas interpretativas de grande relevância) recomendo, pelo menos, os trabalhos de Candeloro (1964 e 1968), de inspiração gramsciana, assim como, para uma obra mais recente, Villari (2009), na brasileira, Barros Filho et al. (2007), Fay e Constantino (2011). Para uma síntese da representação de Garibaldi nas Américas, cf. Fanesi (2007). 
Cristóvão Colombo, que se tornaria um "totem" muito conveniente em várias fases da americanística italiana.

É nesse contexto que vamos encontrar tanto nomes que se relacionam com a $S A P$ quanto trajetórias institucionais que também contribuem a delinear o cenário inicial para a compreensão das origens da americanística italiana. Essas duas polaridades cruzam-se muito frequentemente, como é compreensível: intelectuais "americanistas" ou cooptados por instâncias institucionais da americanística (a própria $S A P$, mas não só) são também protagonistas de empreendimentos institucionais que merecem ser observados mais de perto. Aproximar-se de alguns deles constituirá, agora, um bom começo para os propósitos deste trabalho.

\section{De nomes e instituições: pioneiros, ma non troppo.}

No II Tomo (1898) do Journal de la Société des Americanistes de Paris (p. 307-309) aparece, pela primeira vez na revista, uma lista dos membros da Sociedade (até 31 de dezembro de 1898). São 65 e, entre eles, o único italiano é Enrico Hillyer Giglioli, qualificado come "professeur à l'Institut des Études supérieures de Florence, Italie". Ao seu lado, encontram-se alguns diplomatas de países americanos (Costa Rica, México, Estados Unidos, Canadá), professores e dirigentes de instituições de pesquisa ou museus americanos, entre os quais se destacam Francisco Moreno, diretor do Museu de História Natural de La Plata, Francisco del Paso y Troncoso, diretor do Museu Nacional de México, John W. Powell, fundador (em 1876) e diretor do Bureau of American Ethnology do Smithsonian Institute, então a maior instituição de pesquisa dedicada à etnografia, arqueologia e linguística das populações nativas norte-americanas, e Frederic W. Putnam, diretor do Peabody Museum of Archaeology and Ethnology, da Universidade de Harward. Na lista também aparece o expresidente da República Argentina, Bartolomé Mitre que, nesse ano de 1895, estava praticamente retirado da política e se dedicava a atividades intelectuais. Finalmente, entre os membros da Société figuravam vários representantes da sociedade francesa da época, recrutados tanto na aristocracia quanto na alta burguesia. 
$\mathrm{Na}$ relação de membros publicada onze anos depois, em 1909, encontram-se mais personalidades latino-americanas, como Juan Ambrosetti (1865-1917), que em 1904 havia impulsionado a criação do Museu Etnográfico da Faculdade de Filosofia da Universidade de Buenos Aires; Florentino Ameghino (1854-1911), destacadíssima figura intelectual argentina da época, Robert Lehmann Nitsche (médico e etnólogo alemão radicado na Argentina), Samuel Alejandro Lafone Quevedo, sucessor de Moreno na direção do Museo de La Plata ${ }^{10}$, Manuel González de La Rosa (1841-1912), erudito peruano que, assim, foi o primeiro a representar na Société o país cujo passado tanto atraía os americanistas europeus ${ }^{11}$. Argentina, México e Peru são, portanto, os países latino-americanos mais representados nos quadros sociais da SAP. Um olhar muito provisório e superficial às temáticas abordadas nos artigos dos primeiros anos do Journal de la Sociétêt ${ }^{12}$ permite verificar que o primeiro desses três países desperta, sobretudo, a atenção de quantos, sobretudo geógrafos, direcionam seus interesses para regiões cuja descrição ainda merecia esforços notáveis, como a Patagônia e a Terra do Fogo, ao passo que os outros dois estavam no centro das atenções de todos aqueles que, sobretudo arqueólogos ou historiadores, se interessavam pelas "antigas civilizações" inca e asteca ${ }^{13}$. Vale

\footnotetext{
${ }^{10}$ A historiografia argentina sobre a ciência do país no século XIX, e sobretudo das trajetórias institucionais dos seus primeiros museus e dos seus dirigentes, é extremamente ampla e significativa. Indico, por brevidade, a leitura de: Stagnaro (1993), Arenas (1990), Podgorny et alii (2015a e 2015b), Podgorny e Lopes (2014) e Podgorny (1997). Cabe lembrar que, apesar de ambos figurarem na lista de membros da $S A P$, as relações pessoais e institucionais entre os paleontólogos Ameghino e Moreno eram tão pouco pacíficas que foram rotuladas, em uma oportunidade, como la guerra de los huesos. Cf. Podgorny (1997).

${ }^{11}$ Sobre esse intelectual, cf. Riviale (1997)

12 Toda a revista, desde o primeiro número de 1895 até hoje, está disponível, em acesso aberto, em https://journals.openedition.org/jsa/

${ }^{13}$ Quase não há participação brasileira na $S A P$. Desde a primeira lista de 65 membros de 1895, porém, aparece o nome "Santa-Ana-Nery (Baron de)", domiciliado a "91, rue de la Bèotie, Paris". Trata-se de Frederico José de Santa-Anna Nery, nascido em Belém do Pará em 1848 e falecido, em 1901, na mesma cidade, depois de ter vivido de 1862 até 1897 na Europa (Roma, Florença e, sobretudo, Paris), tornando-se uma figura singular nas relações políticas, culturais e literárias entre o Brasil (notadamente em coisas da Amazônia, de que se tornou um grande divulgador, com uma lista extensa de publicações) e o velho continente (Coelho, 2007). Assim sendo, seria necessário observar a situação do maior país da América Latina que "participa" do movimento americanista - aparentemente - apenas como território de estudo. Considerando apenas o interstício entre a primeira edição publicada do Journal (1895) até a última (1913), antes da longa pausa causada pela eclosão da I Guerra Mundial, perfazendo um total de 18 tomos, o Brasil aparece indiretamente, em resenhas de livros ou como tema principal ou acessório de artigos. As publicações do $J S A$ são retomadas em 1919. Valeria, porém, acrescentar o nome de Capistrano de Abreu, que teve intensa colaboração com "sulamericanistas" sobretudo alemães e franceses, tendo sido sócio correspondente da "Gesellschaft für Anthropologie, Ethnologie und Urgeschichte" [Sociedade de Antropologia, Etnologia e Pré-História] de Berlim desde 1895, mas não da SAP, ainda que o seu Journal de la
} 
também lembrar que na lista de 1909 também aparecem Franz Boas (18581942), que, havia dez anos, estava lecionando antropologia na Columbia University, e, sobretudo, Paul Rivet (1876-1958). O então jovem médico francês havia voltado da longa estadia americana, iniciada com a participação na missão geodésica francesa no Equador (1899-1906) e, em poucos anos, se tornaria figura de proa da etnologia e da americanística francesas e, desde 1907, membro titular da $S A P$, de cujo Journal seria logo um dos autores mais prolíficos, e, de 1922 até a sua morte, seu Secretário-Geral ${ }^{14}$.

A presença italiana na $S A P$, na relação de membros de 1909 , triplica. Ao lado de Giglioli, comparecem Aldobrandino Mochi e, sobretudo Guido Valeriano Callegari, o primeiro e mais destacado "americanista" italiano entre os séculos XIX e XX. Aqui, vamos considerá-lo como um "iniciador", cujo "círculo" agora interessa reconstruir, acompanhar e analisar, para verificar se é nele ou em volta dele que se articula e se desenvolve o conjunto de interesses culturais da inteligência italiana para com as Américas.

Antes, porém, é necessário destacar o fato de que as presenças de Giglioli e Mochi são também muito significativas, mas, paradoxalmente, pela grande ausência que elas sinalizam implicitamente. Embora muito distintas entre si, as trajetórias dessas duas figuras (inclusive em termos de quantidade de capital simbólico acumulado, nacional e internacionalmente) estão estreitamente ligadas a um dos mais proeminentes intelectuais italianos dessa época, o médico (e antropólogo e americanista), Paolo Mantegazza (1831-1910), que, porém, não chegou a ser membro da $S A P$.

Enrico Hillyer Giglioli, nascido em Londres em 1845, filho de um médico e antropólogo que acumulara vários períodos de exílio por motivos políticos, se criou na cidade de Gênova e completou os seus estudos em Pavia e em Londres (1861). Nos anos londrinos, especificamente, esteve em contato com o círculo de cientistas próximos de Charles Darwin, apenas dois anos

Société des Américanistes de Paris tenha publicado tanto artigos da sua autoria como resenhas sobre a sua produção etnográfica e linguística (Christino 2007).

14 É por demais conhecido o papel que Rivet desempenharia na institucionalização da antropologia na Colômbia, país onde chegou em 1942 e, além de fundar o Instituto Etnológico Nacional, foi o formador da primeira geração de antropólogos colombianos. Cf., entre outros, García Botero (2010) e Laurière (2009a e 2009b). 
depois da publicação do Origin of Species (Barbagli, 2014), entre os quais Thomas Huxley - o que contribuiu para que ele se tornasse, pouco mais tarde, um dos mais destacados darwinistas italianos ${ }^{15}$. Formado em Ciências Naturais na Universidade de Pisa, em 1864, um ano depois, recebeu o convite para participar de uma grande expedição marítima: um navio militar italiano, o "Magenta", realizaria a circum-navegação da Terra, com finalidades políticodiplomáticas e científicas ${ }^{16}$. A viagem começou em Nápoles e, depois de etapas no Rio de Janeiro e Montevidéu, dirigiu-se para sudeste, pelo Atlântico austral, rumo à Ásia, fazendo etapas em vários portos, inclusive da China e do Japão, até chegar em junho de 1867, a Sidney. De lá, pelo Oceano Pacífico, a rota tocou portos do Peru, do Chile, da Patagônia, novamente Montevidéu, para finalmente voltar para a Itália. Giglioli fez uma crônica detalhadíssima dessa viagem numa obra de mais de mil páginas, publicada em 1876 com o título de Viaggio intorno al globo della r. pirocorvetta italiana Magenta negli anni 1865-66-67-68: uma "Relazione descrittiva e scientifica" em formato de diário de bordo. O texto tem observações de toda espécie, com destaque para a zoologia, a botânica, a antropologia, a etnologia e a meteorologia e veio a lume com uma "Introdução etnológica" do professor Paolo Mantegazza, de quem Giglioli se tornaria colega, antes, e amigo, depois, a partir de 1869, quando é convidado para a cátedra de Zoologia dos Vertebrados no "Istituto di Studi Superiori Pratici e di Perfezionamento" de Florençca ${ }^{17}$, cuja cátedra de “Antropologia e Etnologia”, nesse mesmo ano, foi também criada e ocupada justamente por Paolo Mantegazza. Este, por sua vez, foi um dos intelectuais italianos mais conhecidos da sua época, inclusive no exterior. Concluído o curso de Medicina em Pavia, em 1854, fez uma primeira e longa viagem à

\footnotetext{
15 Para além dos principais trabalhos italianos que abordam a biografia e a trajetória intelectual desse personagem (cf. D’Entreves et al, 1996 e Barbagli, 2014), veja, no Brasil, Fernandes et al. (2010 e 2012).

16 A Itália era um país independente desde 1861 e o objetivo principal da viagem era o estabelecimento de relações diplomáticas e comerciais com vários países do mundo, sobretudo no extremo leste. Além disso, alguns dos participantes da expedição, entre os quais o Giglioli, receberam do governo italiano também tarefas de exploração geográfica e naturalística, que acabaram ficando sob a responsabilidade direta do jovem Giglioli, depois do adoecimento e da morte, durante a viagem, em Hong Kong, do chefe da missão científica, Filippo De Filippi, o mais célebre zoólogo da época, primeiro divulgador das teorias de Darwin no país (cf. Cimino, 1987 e Canadelli, 2012).

17 A história da Universidade de Florença, fundada em 1321, foi conturbada, devido aos contextos políticos e militares da história italiana. Em 1859, dois anos antes da independência e da unificação da Itália e seis anos antes de Florença se tornar capital do país, foi criado o Instituto de Estudos Superiores e de Aperfeiçoamento, que em 1924 seria um dos núcleos da nova Università di Firenze (Rogari, 2005).
} 
América do Sul (Argentina, Brasil, Paraguai e Bolívia), onde viveu até 1858, tendo fixado sua residência principal em Salta, onde se casou com uma mulher argentina com quem teria quatro filhos, realizando também observações sobre várias etnias. Retornou à América do Sul mais duas vezes, em 1861 e $1863^{18}$. Além de ter sido o primeiro catedrático italiano de "Antropologia", nesse mesmo ano de 1869 também foi promotor da criação, ainda em Florença, do primeiro "Museu de Antropologia e Etnologia" e, dois anos mais tarde, da "Sociedade Italiana de Antropologia e Etnologia" e da sua revista, Archivi per l'Antropologia e l'Etnologia' ${ }^{19}$.

Muito em síntese: com Giglioli e Mantegazza estamos diante das duas figuras principais para o nascimento da antropologia italiana (incluindo aquilo que, sendo então denominado "etnologia", apontava para os aspectos sociais e culturais no estudo do homem) e da própria "americanística" - tanto do ponto de vista historiográfico quanto nas implicações simbólicas e ideológicas que a segunda metade do século XIX carrega, forçosamente, quando se olha para ela como um ponto de "início de linhagem". Pensar a história da antropologia e/ou da americanística italianas contemporâneas a partir desses nomes e dessas primeiras instituições e das suas práticas científicas provoca um duplo movimento, capaz, por si só e ao mesmo tempo, de engendrar e de esclarecer questionamentos historiográficos, políticos e epistemológicos: a "rejeição" (pelo que há, nessa época "originária" de ultrapassado e comprometido com ideologias e teorias hoje recusadas, num contexto de "pseudo-ciências") e a “inclusão" (para que nenhum elemento conectivo e significativo no processo de construção desse campo intelectual se perca no caminho). Assim, considero que ao caso italiano, nessas condições, se aplique o alerta da antropóloga argentina Claudia Briones:

Cada vez que revisamos la historia de la Antropologia para actualizar nuestro "estado de cuentas", los antropólogos también invocamos "tradiciones" e incurrimos en omisiones de manera

\footnotetext{
18 A especial atração de Mantegazza pela América do Sul, em que também esteve presente um forte elemento autobiográfico, gerou o seu interesse no estudo da coca e dos seus efeitos. Logo depois da primeira viagem, publicou, em 1859, o ensaio Sulle virtù igieniche e medicinali della coca e sugli alimenti nervosi in generale. Baseado nas suas observações das populações indígenas que apresentavam o uso da Erythroxylum coca. Cf. Aimi (2010).

${ }^{19}$ Os trabalhos biográficos sobre Mantegazza são inúmeros. Limito-me, aqui, a sugerir a leitura de Govoni (2012) e Barbagli (2014). No Brasil, cf. Guerra (2015), na Argentina, Bravo Herrera (2012).
} 
selectiva. Cada vez que queremos ejercitar uma mirada historizada y critica, nosotros también-sabiéndolo o no-tenemos los fantasmas de las generaciones pasadas rondando sobre nuestzras cabezas.

A veces, algunos de esos fantasmas nos recuerdan, como en una pesadilla, clasicas nociones de "cultura" que prefeririamos olvidar. Otras veces, los miramos con otros ojos y descubrimos que aun podemos aprender mucho de ellos y que nadie puede arrogarse el privilegio de decir, de una vez y para siempre, quiénes son los "buenos" y los "malos" de la pelicula. En mi propia experiencia, "mis" buenos y malos fantasmas a veces intercambian roles, segun qué historia quiero contar, cuando, dónde y para qué o quién lo hago. En este sentido, recontar historias es una forma de detenernos a pensar dónde estamos "ahora" parados y a dónde queremos ir (BRIONES, 1994, p. 117) ${ }^{20}$.

À síntese agora apresentada, então, ainda é necessário acrescentar que as relações entre Giglioli e Mantegazza, em Florença, foram longas, intensas e significativas. Apesar da diferença de quase quinze anos de idade, desempenharam, em conjunto, um papel decisivo na origem dos dois campos aqui considerados. As duas carreiras científicas, inclusive, iniciaram com duas viagens (Barbagli, 2014: 169), nas quais (em que pese a longa passagem asiática), a América do Sul é eixo central, e determinante para os seus interesses antropológicos $^{21}$. Curiosamente, porém, coube ao “antropólogo” (Mantegazza), trazer uma rica coleção naturalística (objeto de doações ao Museu de História Natural de Milão), e ao "zoólogo" (Giglioli) voltar da sua viagem com uma grande quantidade de "objetos etnográficos", doados tanto ao próprio Museu Antropológico de Florença, quanto ao Museu Etnográfico "Pigorini”" de Roma $^{22}$. Entretanto, apesar disso, não é possível considera-los "pioneiros" da americanística" italiana, nem mesmo avant la lèttre, justamente pelo pequeno peso dos temas americanos, nas suas produções científicas.

20 Também me inspiro na e tento seguir a tradição de estudos que, de certa forma foi inaugurada no Brasil pela saudosa Mariza Corrêa (2001), que, em As Ilusões da Liberdade, no começo dos anos Oitenta, se dedicou ao estudo da chamada "Escola Nina Rodrigues", também na base de uma robusta linhagem da antropologia brasileira. Um dos resultados mais consistentes dessa tradição é também o livro de Lilia Moritz Schwarcz (1993), que inclusive se posiciona no mesmo quadrante cronológico deste meu mais modesto trabalho.

21 Alliegro (2011, p. 82) lembra, oportunamente, que Mantegazza e Giglioli foram praticamente os únicos - "com poucas exceções" - a realizar estudos, inclusive de cunho etnológico e, no caso de Giglioli com grande interesse pela cultura material, a partir de experiências "de campo".

22 Os movimentos de formação e manutenção das coleções americanas nos museus italianos entre a segunda metade do século XIX e o começo do XX são objeto de numerosos estudos. Cf, especialmente para os museus de Roma e de Florença, Abbatista (2013), Barbagli e Pratesi (2009), D’Orta (1992), Fernandes at al (2010), Moggi Cecchi e Roscoe (2014), Rodrigues (2017) e Petrucci (1983). 
Finalmente, a presença de Aldobrandino Mochi entre os membros da SAP torna mais estranha a ausência de Mantegazza, justamente porque Mochi (1875-1931) foi discípulo, colega e, depois da morte do chefe, em 1910, herdeiro intelectual e continuador da obra de Mantegazza tanto no Museu de Antropologia e Etnologia de Florença quanto na Cátedra de Antropologia e na Sociedade italiana de Antropologia e Etnologia. Tendo se tornado um antropólogo físico e, sobretudo, paletnólogo de renome internacional, nunca teve, porém, relações com as Américas, tendo, sim, realizado viagens e se interessado pelas culturas africanas, asiáticas e italianas (Moggi Cecchi e Roscoe, 2014). Seja como for, nem Giglioli nem Mantegazza (apesar da relevância que a América do Sul reveste na suas respectivas trajetórias biográficas e intelectuais) nem, muito menos, Mochi, são ou podem ser considerados "americanistas" 23 no sentido que, estava consignado, em clausula pétrea, no artigo primeiro do Estatuto da SAP: "étude historique et scientifique du Continent Américain et de ses habitants depuis les époques les plus anciennes jusqu'à nos jours $^{22}$. Um sentido que, pelo contrário, estava muito presente na biografia, na obra e nos textos de Guido Valeriano Callegari, o que aqui considero o primeiro "americanista" italiano.

\section{Callegari e em volta dele: um círculo ou um fosso?}

Nascido em Parma, em 1876, Guido Callegari transfere-se ainda criança para Pádua, onde, em 1902, se forma em Geografia. Segundo o que ele mesmo registraria num pequeno memorial (Callegari, 1946), data dessa década o seu interesse pelos "estudos de americanística" e pelas "antigas civilizações americanas", mais especificamente a mexicana. Depois de publicar alguns

\footnotetext{
${ }^{23}$ Entretanto, valem os registros relativos ao fato de que Giglioli participou do XVI Congresso dos Americanistas, em Viena (1908), apresentando três comunicações, intituladas "In torno a due rari cimeli precolombiani delle Antille, molto probabilmente da Santo Domingo, conservati nel Museo Etnografico di Firenze", "Datos acerca del Códice de Vespuccio, existente en Florencia, y necesidad de publicarlo con notas críticas" e "Di certi singolari pettorali in pietra ed in conchiglia precolombiani dalla Venezuela, probabili effigi del dio Vampiro degli antichi indigeni dell'America Centrale" e que, quando em 1926 se realizou em Roma o XXII Congresso Internacional dos Americanistas, figurou na programação oficial uma excursão a Florença, onde seria inaugurado um busto de Paolo Mantegazza. Cf. Rivet (1926). Mochi, por sua vez, esteve presente na sessão de Buenos ires do XVII Congresso (em 1010), com uma comunicação sobre "Crani e scheletri di Indigeni del Chaco".

24 Apud Laurière (2009b, p. 98). Um sentido que acaba confluindo para uma definição da americanística como o conjunto de interesses (científicos ou não, e anteriores à institucionalização de muitas disciplinas "modernas") voltados para as línguas, as culturas, as religiões e a arqueologia americanas.
} 
artigos, em 1908 saem a lume, às suas próprias despensas, os dois volumes (mais de 400 páginas) de L'Antico Messico. Storia e Civiltä ${ }^{25}$, que ele apresentou no XVI Congresso dos Americanistas em Viena, 1908, justamente no ano que antecedeu a sua admissão na $S A P$. Sua primeira viagem ao México foi em 1923, a convite do governo do país, e, nessa oportunidade, Callegari se dedicou ao que ele mesmo definiu "investigações arqueológicas", o que ocorreria novamente em 1928. No mesmo memorial, ele declara ter sido o responsável para levar o XXII Congresso dos Americanistas para a Itália (Roma). De fato, a escolha da capital italiana para sediar o evento se deu durante o XXI Congresso $(1924)^{26}$, em Gotemburgo, na Suécia. Do simpósio romano, Callegari seria o Secretário Geral, junto a um outro grupo de estudiosos italianos que, nesse ano de $1926^{27}$, incluiu notórios personagens próximos ao regime autoritário de Benito Mussolini, dos quais, porém, ele se distanciaria nos anos seguintes, segundo Pasquali $(2016)^{28}$. O próprio Mussolini, na sua qualidade de chefe do governo italiano, pronuncia o discurso de encerramento do congresso, no qual anuncia a criação de uma "Società degli Americanisti d'Italia" (Gandini, 2001: 168), projeto que, porém, só se concretizaria quase dez anos depois.

\footnotetext{
25 O livro seria resenhado no Journal de la Société des Americanistes por Louis Capitan (1908, p. 123-124), estudioso da pré-história francesa, que elogia o trabalho e, sobretudo, a disposição de Callegari, que "[...] a à sa disposition l'intelligence, la puissance de travail et la jeunesse [...]".

${ }^{26}$ Por sua vez, a escolha da cidade sueca se deu no congresso anterior, o XX, sediado no Rio de Janeiro em 1922, como parte das comemorações do centenário da Independência. Cf. Martin, 2008, pp. 36-37.

${ }^{27}$ Pela cronologia oficial do regime, o "quarto" ano depois da tomada do poder por parte do Partido Nacional Fascista de Benito Mussolini. O estudo e a análise das relações entre o fascismo e a americanística italianos extrapolam as possibilidades e os objetivos deste trabalho, mas se trata de uma tarefa que julgo necessária, ainda que potencialmente espinhosa.

${ }^{28}$ Sobre essa questão, que não é possível esgotar aqui, é necessário, entretanto, mencionar pelo menos o fato de que Callegari, em 1940, publicou um artigo na revista fascista Difesa dela Razza, periódico que, entre 1938 e 1943, serviu de suporte jornalístico e "científico" às leis raciais que a Itália promulgou na esteira do governo de Hitler (Lorè, 2008 e Cassata, 2008). Trata-se de um texto dedicado à produção artística de um pintor venezuelano radicado em Roma, Pedro Centeno (1904-1988), frequentemente elogiado por sua adesão à estética fascista. Embora não seja isso que Callegari destaca no seu texto (intitulado, significativamente, "Il pittore dela razza: Pedro Centeno visto da um americanista", o autor menciona numa nota de rodapé uma frase que o pintor lhe escreveu numa carta privada: "Moro em Roma, porque é na Mãe da Latinidade que encontro o clima necessário à minha criação de Artista latino-americano; e sou fascista de alma e de coração, porque o Fascismo tende ao triunfo do espírito latino no mundo" (apud Callegari, 1940, p. 15, tradução minha). Cf. também Esteva-Grillet (2011), que mostra que a leitura de Callegari sobre as relações entre a arte de Centeno e as culturas latinoamericanas é equivocada.
} 
Pouco antes do Congresso de Roma, em 1925, Callegari é aprovado no concurso para a cátedra de "Antiguidades Americanas" que acabara de ser instituída junto à Universidade Católica de Milão (Pasquali, 2014) ${ }^{29}$ Leciona ali até 1935 quando, por motivos não esclarecidos, a cátedra é suprimida. De 1928 a 1935 participou de todos os Congressos dos Americanistas: em Nova Iorque (o XXIII), em Hamburgo (o XXIV, em 1930), na Argentina (o XXV, em 1932), e do XXVI, em Sevilha (Callegari, 1946, p. 4). Nessas oportunidades, além de representar a Itália, por indicação oficial do Ministério da Educação Nacional, ele já circularia entre colegas de outros países com o prestígio de quem fora o responsável pelo evento romano e por mais de duzentas publicações de argumento arqueológico e histórico relativas às Américas. Antes e depois, até sua morte em 1953, a sua biografia é salpicada de atividades relacionadas à arqueologia, mitologia, história e cultura do México e de outras regiões americanas, entre as quais a organização de mostras, a participação em eventos científicos e de divulgação científica, além de palestras e conferências em várias cidades italianas.

$\mathrm{Na}$ realidade, se enquanto animador, docente e administrador ele foi um "americanista", do ponto de vista do estudioso, do pesquisador, Callegari foi, mais propriamente, um "mexicanista", tendo dedicado praticamente toda a sua produção bibliográfica e as suas missões de investigação às antigas civilizações daquela região americana. Também é possível compreender a sua atuação como sendo situada a meio caminho entre a esfera acadêmicocientífica propriamente dita e o trabalho de um "diletante". A curta passagem por uma instituição universitária enquanto docente, e a intermitência de suas atividades de investigação iluminam e correm paralelas ao próprio estatuto da americanística italiana, nem ainda uma disciplina reconhecida oficialmente pelo meio intelectual e científico, nem mais um passatempo de eruditos. Um campo em transição, como veremos, que necessitará de "alianças" com outras disciplinas e campos de conhecimento, para poder se afirmar. E é justamente essa aparentemente escassa densidade teórica de Callegari, sobretudo com relação às disciplinas que nos anos em que ele atuou estavam buscando espaço

${ }^{29} \mathrm{Na}$ banca do concurso, segundo o próprio Callegari (1946, p. 1), estavam Aldebrandino Mochi e o prof. Raffaele Pettazzoni, personagem que encontraremos logo adiante, além do geólogo e geógrafo Giotto Dainelli. 
institucional, na Itália, para a sua definitiva afirmação - sobretudo antropologia e etnologia - a pesar negativamente sobre a sua trajetória e, na minha leitura, para o empreendimento americanista como um todo.

No texto que ele escreve em 1946, uma espécie de despedida e testamento intelectual de quem, envelhecido e doente, confessa com amargura não ter mais forças e ânimo para continuar o seu trabalho de estudioso, Callegari lamenta, também, o estado em que se encontra a americanística italiana. O fechamento da cátedra milanesa e, nas entrelinhas, o escasso apoio oficial a um campo de estudos que, apesar de tudo, não despertara maior interesse na Itália fascista, voltada - militar, política, intelectual e ideologicamente - para a África oriental, são as maiores decepções do nosso pesquisador, já septuagenário. Encerrando o texto, aparece uma nota de rodapé em que ele redige uma espécie de lista de colegas, sinal, ao mesmo tempo, das possibilidades e das fraquezas da americanística naquele contexto:

Fra gli italiani del tempo attuale cultori di res americanae, per la geografia e la storia della geografia, noto l'Almagià, il Magnaghi, il Revelli, il Riccardi, il Michieli, l'esploratore P. De Agostini e i padri Tonelli e Borgatello; nella geologia e paleontologia il Frenguelli, Direttore del Museo de Historia Natural de la Plata, nell'antropologia e etnologia il Biasutti, il Cipriani, il Corso, il Genna, il Marro, il Sera, il Sergi, l'Imbelloni del Museo de Historia Natural de Buenos Aires; nella linguística, dopo l'immatura scomparsa del Trombetti, Matteo Bartoli a Torino, il Vignali a La Plata, B. Ferrario a Montevideo, il Galante a Lima; nell'archeologia mons. Lunardi, ora vescovo di Honduras, il Bazzocchi, il Mazzini, il Mordini; nella mitologia e religione S. E. Pettazzoni; nella sociologia il Gini, il Camavitto, nella storia il compianto Conte Perrone di San Martino e ricorderò pure doverosamente l'alta opera de' nostri valorosi Missionari e quella divulgatrice e geniale dela compianta Maria Savi-Lopez e del capitano Benedetto Giacalone (Callegari, 1946, p. 5).

Cerca de trinta nomes, quase todos vivos nesse ano de 1946, com apenas três exceções. Mesmo descontando a possibilidade de alguma omissão devida a desconhecimento, inimizade ou idiossincrasia por parte de Callegari, parece estar configurado um "campo" de reduzidíssimo tamanho. Nele, o nosso autor inclui também figuras já radicadas na América do Sul, como José (ou Giuseppe) Imbelloni (nascido na Calábria em 1885 e transferido na Argentina em 1921, onde se tornaria um dos mais proeminentes nomes da 
antropologia e da paletnologia) ${ }^{30}$, Joaquín (Gioacchino) Frenguelli (nascido em Roma em 1883, emigrado para a Argentina em 1911, seria professor de geologia, paleontologia e geografia física e, de 1935 a 1946, diretor do prestigioso Museu da Universidade de La Plata) ${ }^{31}$, Benigno Ferrario (nascido em 1887 na Itália, onde se tornara um especialista em línguas africanas e afroasiáticas, e radicado desde 1923 no Uruguai, onde se dedicaria ao estudo de línguas da Patagônia e do Chaco, além de lecionar na Universidad de la República) ${ }^{32}$, e o próprio padre Federico Lunardi (nascido em Livorno em 1880 e falecido em Asunción em 1954, que esteve a serviço da diplomacia do Vaticano, desde 1916 até a sua morte, sempre na América Latina - Cuba, Chile, Colômbia, Brasil, Bolívia, Honduras e Paraguai - tendo sido autor de importantíssimos estudos e trabalhos de cunho etnográfico ou arqueológico) ${ }^{33}$.

Mas ao lado destes italianos já "latino-americanizados", figuram ainda mais de vinte e cinco nomes de intelectuais que desempenharam as suas atividades na Itália nos anos contemporâneos à atuação de Callegari ${ }^{34}$. Na próxima seção, destaco sumariamente a trajetória de alguns deles, selecionados com base na proximidade institucional entre as suas atuações científicas e o surgimento dos estudos etno-antropológicos italianos, mas, também, no grau de aproximação ou afastamento nas questões que, na época, podiam ser consideradas propriamente americanistas. Para defini-las, sirvo-me de parte do texto que Callegari redigiu como verbete para a Enciclopedia Italiana ${ }^{35}$, em 1929:

\footnotetext{
${ }^{30}$ Cf. Arenas (1990).

31 Cf. Podgorny, 1997. Frenguelli participou de dois congressos internacionais dos Americanistas: em 1926, em Roma, apresentou, em italiano, "Sull'origine dell'uomo americano" e, em 1932, em La Plata, em espanhol, "El problema de la antiguedad del hombre en la Argentina" (Comas, 1974, p. 146).

${ }^{32}$ Cf. Rosa (2013).

${ }^{33}$ Cf. Cavallo (2013) e Fulvi (1979).

${ }^{34}$ Entre os dois grupos, coloco a figura singularíssima de Ippolito Galante. Nascido em Roma em 1892, esse conhecido filólogo e latinista inseriu o Peru no seu périplo pelo mundo, tendo sido, também, professor em Santiago do Chile, em Coimbra, em Uppsala e Estocolmo, em Salamanca e em Nova Dheli, além de Lima, onde atuou como fundador e diretor do Instituto de Filología da Universidad Nacional Mayor de San Marcos entre 1936 e 1938, se tornando um especialista em quechua. Cf. Durston (2014). Desde 1951, foi professor de "Línguas da América Precolombiana" na Universidade de Roma (Gandini, 2006b).

35 A Enciclopedia Italiana di Scienze, Lettere ed Arti é a mais célebre enciclopédia italiana, que começou a ser publicada em 1929, em 35 volumes, por parte do Instituto da Enciclopédia Italiana, criado em 1925. Nos seus noventa anos de vida, tem contado, entre os seus dirigentes, editores e colaboradores, com os nomes mais relevantes da cultura da Itália, tanto na época fascista quanto, a partir do pós-guerra, com a redemocratização. O verbete de Callegari saiu no segundo volume, publicado em 1929, e continua constando da edição atual, inclusive na versão
} 
AmericAnísticA. Por Americanística entende-se o conjunto de estudos e de pesquisas que têm por objetivo o conhecimento científico da América e dos seus habitantes, com referência especial à civilização da época pré-colombiana. Ela investiga e estuda as múltiplas manifestações dessas antigas civilizações; origem, desenvolvimento, vida, religiões, leis, costumes, artes: ou seja, tem a mesma tarefa da egiptologia e da assiriologia para o mundo antigo. (Callegari, 1929; tradução minha)

O caput do verbete afirma uma definição "antiguizante" e "arqueologizadora" da americanística, que seria assim uma disciplina concentrada principalmente sobre as civilizações antigas, assim como, justamente, a egiptologia não se interesse pela cultura (etc.) do Egito moderno e contemporâneo. Ao longo do verbete, essa visão vai parcialmente se matizando, como quando, por exemplo, se afirma que

Como se vê, a americanística, ainda que sustentada e necessariamente completada por tais conhecimentos [problemas geográficos, históricos, etnográficos mais “modernos”], é possível afirmar que tenha uma característica peculiar que a diferencia de investigações semelhantes realizadas em outros continentes. O seu núcleo central é constituído sem dúvida pela arqueologia précolombiana, com a qual no passado se identificou, enquanto, com o passar do tempo, ela ampliou o seu campo de estudos. Das culturas indígenas ela busca a origem e o desenvolvimento, inclusive através das fontes dos escritores indígenas e espanhóis da época das conquistas - na sua maioria religiosos - e com método crítico procura compreender as grandes transformações sofridas, aclarar os acontecimentos mais notáveis durante todo o período colonial e deste até os dias de hoje (Ibidem, tradução minha, grifo do autor).

De fato, a definição de 1929 acabaria sendo flexibilizada, ainda que parcialmente. Dessa flexibilização participaram também os debates que se travam nos congressos internacionais dos americanistas: se em 1875 o art. $1^{\circ}$ do Regimento dos Congressos reza "O Congresso Internacional dos Americanistas tem por objeto contribuir para o progresso dos estudos

digital, disponível online: http://www.treccani.it/enciclopedia/americanistica \%28Enciclopedia-Italiana \%29/ (acesso em 16 de abril de 2019). Ele publicou mais 69 verbetes na mesma obra, quase todos de assunto americano, mas sobretudo mexicano, entre os quais "Aztechi", "Toltechi", "Zapotechi", "Michoacan", "Quetzalcóatl", "Popol Vuh", "Quechua”, "Cuzco", "Atahaualpa" - todos ainda disponíveis online. 
etnográficos, linguísticos e históricos relativos às duas Américas, especialmente para as épocas anteriores a Cristóvão Colombo [...]" (apud Comas, 1974, p. 45, tradução do francês minha), em 1900, o mesmo artigo encurta e amplia o escopo dos congressos: "O Congresso Internacional dos Americanistas tem por objeto o estudo histórico e científico das duas Américas e dos seus habitantes" (ibidem, p. 48, tradução do francês minha) ${ }^{36}$.

Em 1935, nove anos depois da "promessa" de Mussolini, é criado, em Turim, o CISA - "Centro Italiano di Studi Americani” (Gandini, 2001b, 168). Gestado ao longo de vários anos, o seu nascimento se dá sob a batuta de um personagem muito controvertido, o jornalista calabrês Pietro Gorgolini (1891$1973)^{37}$. Fascista da primeira hora (antes mesmo da tomada do poder de Mussolini em 1922), protegido pelo chefe do governo, teve toda a sua carreira ligada ao regime, fundando e colaborando em inúmeros veículos da imprensa fascista e filo-fascista. Entretanto, desde o final da década anterior, Gorgolini havia começado a colecionar livros de assunto americano, chegando a planejar a publicação uma obra em dez tomos sobre os indígenas americanos - que nunca veio a lume. Segundo D’Orsi (2002), tratava-se de mais de dez mil volumes, que constituiriam justamente o acervo inicial do CISA, em Turim. O Centro será a primeira instituição italiana a se instituir como "americanista". Mas a sua composição, observada e compreendida através das trajetórias dos seus membros mais proeminentes reservará algumas surpresas.

\footnotetext{
36 Menos sintéticos seriam os "debates" travados ao longo dos primeiros congressos, acerca de outras questões de "pertinência" temática, que, resenhados rapidamente por Comas (1974, p. 15-22), ilustram a diversidade de abordagens e pressupostos, dos primeiros americanistas globais - e algumas bizarrices. Sobre elas, Paul Rivet comentará, em 1930: “A impressão que emerge dos trabalhos desses primeiros Congressos é uma impressão de entusiasmo, juventude e inexperiência. Enquanto a América ainda era tão mal e tão pouco conhecida, são os problemas mais difíceis que atraem os pesquisadores [...] Estas são as teses mais aventurosas que tentam os Congresistas. Muitas delas ou foram completamente abandonadas pela ciência moderna ou ainda estão em discussão no momento: a descoberta da América pré-colombiana, os fenícios na América, o Budismo na América, Atlântida, [...] A Linguística oferece os temas mais ousados: comparando as línguas indígenas com o dinamarquês, com o Basco, com o baixo Bretão" (apud Comas, 1974, p. 15, tradução do francês minha). Só como exemplo, no Congresso do Rio (1922) a apresentação do trabalho "A antiguidade americana", por Carlos Xavier Paes Barreto, defende a existência da Atlântida e negando que a América tivesse sido descoberta por Colombo (Comas, 1974, p. 150). Barreto (1881-1969), foi um jurista e político pernambucano. No Congresso de Roma (1926), o linguista Alfredo Trombetti, defensor da teoria monogenética das línguas, apresentou "Origine asiática delle lingue e delle popolazioni americane" (Coma, 1974, p. 174).

37 As informações biográficas sobre Gorgolini encontram-se em D’Orsi (2002). Para a sua participação nos empreendimentos americanistas, cf. Gandini (2002).
} 


\section{O Centro Italiano de Studi Americani: uma rede à margem.}

O CISA dota-se logo de um comitê provisório, encarregado de encaminhar e organizar as suas primeiras atividades e a sua estrutura. Integrado por Callegari, Gorgolini e mais nove membros, o seu "presidente de honra" foi Arturo Farinelli. Este (1867-1948) figura na história intelectual italiana como um filólogo e crítico literário e, sobretudo, "germanista". Entretanto, nessa posição especialística e através da leitura e do estudo da obra de Wilhelm von Humbdolt (irmão de Alexander), ele também chegaria ao "hispanismo". Professor de literatura alemã na universidade de Turim, desde 1907, cultivou o interesse paralelo por essas duas áreas histórico-culturais, a germânica e a hispânica ${ }^{38}$, tendo sido inclusive, colega muito próximo de Marcelino Menéndez Pelayo, nome de destaque na filologia e literatura da Espanha (Gargano, 1993) e tendo praticado, de forma pioneira na Itália, interesses comparatistas (Strappini, 1995). Mesmo assim, não há registro de publicações de Farinelli de assunto americano ${ }^{39}$.

Mas, nesse comitê, encontramos também seis dos nomes mencionados por Callegari na sua nota de rodapé, mais o próprio Callegari: Renato Biasutti, Giovanni Marro, Antonio Mordini, Riccardo Riccardi, Maria Savi-Lopez, Sergio Sergi. No confronto entre as duas listas, vale destacar o fato de que naquela redigida em 1946 (portanto depois da queda do fascismo) não comparecem - significativamente - nem Farinelli nem Gorgolini. Seja como for, oportunamente será necessário proceder a uma análise um pouco mais pormenorizada desses nomes que comparecem nos dois lugares. Antes, porém, apresenta-se o primeiro passo público do CISA: o " $1^{\circ}$ Convegno Nazionale degli Americanisti”, que se realizaria em Roma em outubro de 1936.

A sede do Centro já havia sido transferida para Roma, por ordem direta de Mussolini, desde o ano anterior (Gandini, 2001b, p. 168) e é na capital italiana que seria organizado o simpósio (Gandini, 2002, p. 236). O evento foi dividido

\footnotetext{
38 Sua obra de 1929, Italia e Spagna, em dois tomos, é dedicada às relações intelectuais e literárias entre os dois países.

39 Mas redigiu, para a Enciclopédia Italiana, em 1939, o verbete de Luis de Camões: http://www.treccani.it/enciclopedia/luiz-vaz-de-camoes \%28Enciclopedia-Italiana $\% 29 /$. Acesso em 7 de maio de 2019.
} 
em cinco sessões: Antropologia; Arqueologia; Etnologia; História e Geografia; Direito, Política, Sociologia, Estatística, mas, ainda segundo Gandini (ibidem), era finalizado sobretudo à "propaganda política". De fato, a repercussão na imprensa italiana vai nesse sentido, com muitas referências tanto aos discursos dos vários dirigentes fascistas quanto à inflamada intervenção do então embaixador do Brasil junto à Santa Sé, Luís Guimarães Filho ${ }^{40}$, que incluiu uma calorosa saudação a Mussolini. Mas o que esse evento sinaliza, na perspectiva que busco apresentar, é o "esvaziamento" do campo americanista, que nesse momento parece incapaz de desenvolver um projeto epistemológico e científico relevante e, portanto, uma produção capaz de dialogar efetivamente com os demais americanistas europeus ou mesmo de se articular com as instituições científicas americanas. Se não bastasse o fato de a primeira presidência do CISA ter sido ocupada por um intelectual sem nenhuma ligação com o tema (Farinelli), o evento de outubro de 1936 foi aberto por um filósofo e jurista também estranho aos estudos americanos, Francesco Oristano, que concluiu a sua conferência de abertura, intitulada "Civiltà italiana e civiltà americana" afirmando que "as três grandes dádivas oferecidas pela Itália ao mundo, que são a religião universal, o direito e a ciência, também são compartilhadas na América", e que será nesse tripé que Europa e América poderão colaborar para a afirmação da civilização da raça branca"41.

Nesse contexto, é necessário situar a atuação de alguns dos nomes que já foram mencionados. A eles (Biasutti, Marro, Mordini, Riccardi, Savi-López e Sergi, do primeiro comitê provisório do CISA; e Cipriani, Corso, Genna e Sera, da lista redigida por Callegari em 1946), acrescento, finalmente, Roberto Almagià, Paolo Revelli e Giuseppe Mazzini, que aparecerão, desde 1938, no "Comitê de Etnologia Americana", criado dentro do CISA e presidido pelo nome mais relevante, Raffaele Pettazzoni. Todos esses quatro estudiosos também aparecem na nota de rodapé do "testamento" de Callegari: os dois

${ }^{40}$ Luís Guimarães Filho (1878-1940), filho do poeta e diplomata Luís Guimarães Júnior, foi, assim como o pai, membro da Academia Brasileira de Letras e poeta parnasiano. Cf. http://www.academia.org.br/academicos/luis-guimaraes-filho/biografia. Acesso em 29 de abril de 2019.

41 "L'inaugurazione del primo Convegno di Studi Americani nell'anniversario dela scoperta dell'America". L'Osservatore romano, 13/10/1936. Disponível em http://digipoint.unigre.it/ossromano/res/pdf/1936/10/13.pdf, acesso em 29 de abril de 2019. Vale lembrar que o registro está no órgão da Santa Sé, e que o papa, em 1936, era Pio XI, cuja figura ainda hoje è objeto de pesquisas e de controvérsias pelas suas relações com o regime fascista e a sua ideologia, inclusive racial. 
primeiros como ligados à geografia, o terceiro à arqueologia e o quarto à mitologia e religião.

Considero, portanto, que aqui se configuraria uma rede de intelectuais que, a vário título e com intensidades diferentes, se associam a um campo de estudos ainda completamente em formação, mas que, justamente em razão das suas próprias características individuais e das dificuldades oferecidas pelo contexto político (o regime fascista, surgido em 1922, e a eclosão da II Guerra Mundial), não conseguem institucionalizar, deixando essa tarefa para os anos do pós-guerra - como veremos. Poucos deles (além, é claro, de Callegari, embora nas formas "antiguizantes" que já foram comentadas) deixarão uma obra "americanista" consistente.

Articulando as três listas, elas perfazem um grupo de dezesseis intelectuais, cujos perfis passamos agora a abordar muito sinteticamente, tendo em vista as formas e a intensidade da sua participação nessa "rede" que aqui se apresenta ainda em posição de hipótese.

Renato Biasutti (1878-1965), geógrafo formado em Florença onde foi colaborador do Museu e do Instituto de Etnologia e Antropologia, fundados por Mantegazza, de quem foi colega e amigo, assim como de Mochi (Cerulli, 1968). A sua geografia foi, portanto, desde o começo, uma "antropogeografia", que o levou a se interessar pelas populações "exóticas", sobretudo as do Oceano Pacífico, além das culturas "rústicas" italianas. Seu nome permanece pela organização, em 1941, dos três volumes de Razze e popoli della terra, que, inclusive com os acréscimos que ele introduziu nas edições sucessivas (1959 e 1967), constituiu o ponto mais alto a que pôde chegar a etno-antropologia italiana na virada entre a primeira e a segunda metade do século $\mathrm{XX}^{42}$. Docente universitário em Nápoles, antes, e em Florença, depois $(1927)^{43}$, Biasutti

42 A obra, que buscava sistematizar em todos os níveis os conhecimentos provindos de disciplinas "aliadas", como a antropologia física, a paletnologia, a etnologia, a geografia, a linguística, o folclore e a história - o que, à época, fez surgir a expressão "scienze dell'Uomo (Alliegro, 2011, p. 308) -, teve entre os seus colaboradores algumas das nossas personagens: Sergi, Imbelloni, Cipriani, Boccassino, Corso.

${ }^{43}$ Alliegro (2011, p. 262) lembra que no começo do século Xx, na Itália,o campo da geografia estava mais próximo da etnologia do que da antropologia. Mesmo assim, a trajetória de Biasutti iniciou num contexto "antropológico", por causa da proximidade com o círculo mantegazziano de Florença, para depois inserir cada vez mais conteúdos "etnológicos" à sua geografia. 
acumulou um notável capital simbólico, mas quase sem recursos provindos de aportes americanos. As únicas oportunidades em que o seu nome aparece como autor de um texto americanista são alguns verbetes na Enciclopedia Treccani (1929): "América [Antropologia, Archeologia e preistoria, Etnologia, Lingue indigene, Arte e Musica, Storia]" (mas ao lado de mais onze coautores), "Arapaho", “Amerindî", "Navaho”, “Apache”, "Araucani”, "Bororó” e mais duas dúzias de verbetes dedicados a etnias das Américas. No livro de 1941, a sexta parte ("America”) compreende treze capítulos:

I. Le genti indigene dell'America, II. Le culture indigene e di gruppi etnici dell'America, III. I popoli dell'America artica: Eschimesi e Aleuti, IV. Gli indiani del nord-ovest e della California, V. I cacciatori delle selve e delle praterie, VI. Le genti agricole dell'America settentrionale VII. I popoli e le civiltà dell'Antico Messico, VIII. I popoli degli istmi, IX. I popoli andini in generale, X. I Cibcia e i popoli preincaici dell'Equatore e delle Ande meridionali, XI. L'antico Perù, XII. Gli Amazzonici, XIII. I popoli raccoglitori dello scudo brasiliano, della foresta e del Ciaco. Gli australi ed i marginali del Pacifico.

cuja autoria ficou dividida entre Biasutti e José Imbelloni, o que deixa evidente que, mesmo no final dos anos trinta, o organizador não quis confiar a redação de temas americanos a estudiosos italianos, deixando assim um indício sobre a consistência da americanística italiana, ou, pelo menos, do seu prestígio entre as camadas hegemônicas dos campos disciplinares mais consolidados ${ }^{44}$.

Muito distante dos campos acadêmicos, pelo contrário, esteve a única mulher da "rede", Maria Savi-Lopez (1846-1940), uma escritora que hoje definiríamos "folclorista", tendo se dedicado, entre outros gêneros literários, à coleta e à "reescritura" de fábulas e lendas populares ${ }^{45}$. Data de 1894 Miti e legende degli indigeni americani e de 1926 Nei regni del sole. Antiche civiltà americane. No mesmo ano, participou do Congresso internacional dos Americanistas realizado em Roma,

\footnotetext{
44 Vale lembrar que Imbelloni, italiano radicado na Argentina, era desde 1921 professor de Antropología y Etnografía general na Universidade de Buenos Aires, de cujo Museu Etnográfico passou a ser diretor em 1947.

45 De acordo com Perugi (2016), Maria Savi-Lopez foi colaboradora de dois dos mais conhecidos folcloristas italianos da época, Giuseppe Pitrè e Angelo De Gubernatis. Vale informar que De Gubernatis (1840-1913) - que teve intensa e significativa carreira intelectual, chegando a ser catedrático de Sânscrito em Florença e de Literatura Italiana em Roma realizou, em 1896, uma viagem de cerca de cinco meses na América do Sul, tendo passado por Argentina, Uruguai e Chile. De regresso à Itália, publicou em 1898 o livro L'Argentina. Ricordi e letture.
} 
apresentando um trabalho intitulado "Bernal Diaz del Castillo e la vera storia della conquista della Nuova Spagna” (Sorrento, 1928), o que não apaga a sua posição principal, a de autora de textos que oscilam entre reminiscências românticas e o desejo de ampliar e "internacionalizar" os horizontes literários e imaginários da cultura italiana, inclusive recorrendo a fontes pouco conbecidas no país, como as dos próprios cronistas dos dois primeiros séculos da conquista hispânica. Por outro lado, e diferentemente de quase todos os outros nomes aqui selecionados, o nome dela está completamente ausente de outras instâncias acadêmicas de cunbo etno-antropológico.

Outra figura que não parece relacionada ao campo americanista e, mesmo assim, figura na lista de Callegari, é Lidio Cipriani (1892-1962). Trata-se de outro cientista ligado indiretamente a Paolo Mantegazza, tendo sido aluno de Aldebrandino Mochi, em Florença e, desde 1926, livre docente de Antropologia na universidade da cidade toscana e pesquisador no Museu de Antropologia e Etnologia, do qual se tornaria diretor em 1939. Os seus interesses cientificos levaram-no a realizar numerosas viagens: África do Sul, Etiópia, Zâmbia, Tanzânia, Uganda, Sudão, Egito, Líbia (Moggi Cecchi, 1990, Alliegro, 2011). Elas, paralelas ao desenvolvimento do projeto imperial e colonial fascista nas regiões orientais desse continente, fizeram de Cipriani, ao mesmo tempo, um dos mais renomados paleontólogos humanos e antropólogos físicos da sua época e um dos mais ferrenhos defensores da inferioridade racial dos africanos e da necessidade - ou obrigação - das nações europeias se lançarem em projetos coloniais para a exploração econômica do continente. No ano de 1936, o mesmo do "Convegno degli Americanisti", a sua produção de artigos foi muito intensa nesse sentido. Dois anos depois, o seu nome apareceu como um dos dez. signatários do famigerado "Manifesto della razza", um texto considerado o suporte daquilo que, poucas semanas depois, seria o inicio das práticas antissemiticas do governo italiano ${ }^{46}$. Processado por isso em 1945, depois da redemocratização, alegon que o seu nome aparecera no manifesto à sua revelia, o que acabou propiciando a sua absolvição (Moggi Cecchi, 1990) ${ }^{4748}$. Sua

\footnotetext{
${ }^{46}$ Não há relação direta entre as origens, implicações e consequências desse manifesto e do racismo italiano nesses anos, por um lado, e a reconstrução da americanística, por outro. Entretanto, vale lembrar que nessa versão de 1938, o Manifesto afirmava com vigor que a "pura raça italiana" era "autenticamente ariana", mas que uma revisão do texto, em 1942, enfatizou a presença de uma raiz "mediterrânea" na formação da raça italiana, aceitando, assim, as posições de Giuseppe Sergi. Dessa segunda versão se encarregaram, entre outros, dois dos nossos personagens: Sergio Sergi (filho de Giuseppe) e Raffaele Corso (Alliegro, 2011, p. 267). Trata-se, de qualquer forma, de uma temática ainda muito controvertida nas reconstruções historiográficas. Cf. Alliegro (2011, p. 265-314), Cassata (2008), Pizzato (2012) e Lorè (2008).

47 Entretanto, Cipriani assina cerca de trinta artigos na já mencionada revista La difesa della razæa, todos baseados na sua "experiência" de campo na África, um dos quais se intitula "L'incrocio con gli africani è un attentato contro la civiltà europea". No primeiro número, num
} 
figura intelectual é, até hoje, objeto de controvérsias. Ainda nos anos 40, foi um dos colaboradores da obra de Biasutti (Razze e popoli dela terra), redigindo seis capítulos sobre etnias africanas que tinha conhecido e estudado. No final dessa década, a sua trajetória teve uma virada inesperada, pois iniciou quase casualmente uma fase de intensas pesquisas de campo nas ilhas Andaman, no golfo do Bengala, de 1949 até 1955, cerca de 45 anos depois das celebradas etnografias de Radcliffe-Brown ${ }^{49}$. Em resumo, para além das controvérsias ligadas às suas ideias raciais, Cipriani foi um dos antropólogos italianos (no sentido em que se podia ser "antropólogos", no clima epistemológico e político e no contexto institucional da Itália da primeira metade do século XX) mais conhecidos no exterior e menos "provincianos". Mas nem por um instante ele foi um "americanista". Desde o seu primeiro artigo científico de tema "antropológico" (sobre o Australopithecus africanus, em 1927) até o último (sobre as ilhas Andaman, em 1962) só se dedicou a um tema americano duas vezes, quando, em 1926, apresentou ao Congresso Internacional de Roma uma comunicação sobre dois quipus peruanos conservados no Museu de Florença, e, em 1928, no XXIII Congresso, em Nova Iorque, uma sobre "alcuni caratteri del cranio facciale degli antichi peruviani”".

Trajetória muito diferente, em vários sentidos, foi a de outro membro do Comitê de Etnologia Americana do CISA (1938): Roberto Almagià (18841962). Judeu, ele foi atingido pelas leis raciais italianas e obrigado a abandonar a sua cátedra universitária de geografia, na Universidade de Roma. De 1939 até o fim da guerra, trabalhou na Biblioteca Vaticana ${ }^{50}$, publicando sob pseudônimo (Caraci Luzzana, 1988). Sua trajetória, além disso, foi também

artigo intitulado, singelamente, "Razzismo", defende a introdução das medidas racistas na Alemanha e na Itália, sempre a partir de um ponto de vista "antropológico". Cf. http://anpi.it/media/uploads/files/2017/12/difesa della razza a1 n1.pdf. Acesso em 6 de maio de 2019.

${ }^{48}$ Já Alliegro (2011, p. 274) informa que Cipriani foi o único entre os signatários do Manifesto a ser preso e passou sete meses na prisão de Milão.

49 Os dois estudiosos publicaram duas monografias de título idêntico: The Andaman Islanders, sendo o trabalho do britânico publicado em 1922 e o do italiano em 1966. Todas as informações biográficas sobre Cipriani estão em Moggi Cecchi (1990). Na mesma revista que traz esse artigo encontra-se um texto sobre o uso etnográfico da fotografia por parte de Cipriani, que fez largo uso dessa técnica nas suas pesquisas. O Museu de Florença guarda um arquivo de cerca de 30 mil imagens realizadas por ele entre 1927 e 1955. Cf. também Chiozzi (1990).

50 A convite do papa Pio XII que, eleito em 1939, teve relações com o fascismo muito diferente daquelas do seu predecessor, Pio XI, tendo se oposto ao regime e a Mussolini nas formas que lhe foram possíveis. 
“americanista”, tendo publicado, em 1918, um livro sobre Cristóvão Colombo, cujo subtítulo ("Visto por um geógrafo") esclarece a sua posição de geógrafo interessado na América como uma etapa da história da sua disciplina, e, sobretudo, em 1937, uma alentada obra (mais de 500 páginas) intitulada Gli italiani primi esploratori dell'America, em que retoma justamente essa articulação entre história da geografia e conhecimentos americanos. Além disso, tendo participado do Congresso de 1926 em Roma, apresentou dois trabalhos ("Le prime conoscenze dell'America e la cartografia italiana" e "Il mappamondo di Piri Reis e la carta di Colombo del 1498”), ainda de tema cartográfico. A Almagià aproxima-se, sob alguns aspectos, a trajetória de Paolo Revelli (18711956), também geógrafo interessado na história da geografia e na contribuição dos italianos ao conhecimento das Américas, tendo publicado, em 1926, em coincidência com o XXII Congresso Internacional dos Americanistas realizado em Roma, Terra d'America e archivi d'Italia, trabalho de grande utilidade para a localização, em bibliotecas e arquivos italianos, das centenas de obras (gravuras, cartas, planisférios, manuscritos etc.) relativas às viagens às Américas, oitenta das quais são reproduzidas nos anexos do livro ${ }^{51}$. Desde o ano anterior, Revelli fora admitido como "membro titular" da Société des Americanistes de Paris ${ }^{52}$. Dessa forma, é fácil afirmar que Revelli53 e Almagià configuraram, de forma análoga, a vertente da americanística dedicada a explorar o viés "nacional-geográfico" da disciplina, através do enaltecimento (mas, também, do estudo rigoroso e da localização arquivística e epigráfica) da “contribuição" italiana ao conhecimento do continente americano. Que isso tenha se dado ao longo do governo de Mussolini, entretanto, sem ser surpreendente, é, porém, também significativo, sem que por isso, como se observa no caso dos "africanistas" de regime, comporte o endosso do racismo oficial do regime.

\footnotetext{
51 A obra está disponível em: https://archive.org/details/McGillLibrary-hssl terre-americaarchivi-ditalia E101R45-18008/page/n2 Acesso em 30 de abril de 2019. No mesmo ano, no Congresso de Roma, apresentou o "L'area dell'America Spagnuola secondo um geografo italiano del Cinquecento".

${ }^{52}$ Cf. "Actes de la Société". Journal de la Société des Americanistes, Nouvelle Série, vol. 17, 1925, p. $283 . \quad$ Disponível em https://www.jstor.org/stable/44386772?seq=9\#metadata info tab contents. Acesso em 7 de maio de 2019.

53 À aproximação de Revelli à americanística contribui também a redação de dezessete verbetes geográficos para a Enciclopédia Italiana, entre 1929 e 1932. Entre eles, "Brasile", "Amazonas", "Bahia", "Ceará", "Bello Horizonte".
} 
Entretanto, nas listas que aqui estamos percorrendo, encontramos outros três cientistas que ligaram seus nomes aos debates raciais da época, mas que não militaram com efetividade nas fileiras propriamente americanistas. Radicados em Roma, agiram em várias sedes institucionais, entre os quais a "Società Romana di Antropologia", fundada em 1894 pelo então catedrático de Antropologia da Universidade da capital por Giuseppe Sergi, pai de Sergio Sergi (1878-1972). Este, que aparece tanto no primeiro comitê provisório do CISA (1926) quanto na nota de rodapé de Callegari (1946), médico também, como o pai, se destacou como paleoantropólogo e antropólogo físico, e se tornaria titular da cátedra de antropologia na universidade de Roma, em 1925, herdada do pai, assim como herdara a presidência da Società, em 1916. Sua atividade científica incluiu publicações de 1902 a $1972^{55}$, mas somente três são de assunto vagamente americano: "I rilievi cerebrali delle fosse temporali nei crani deformati del Perī" (1910), outro sobre o mesmo tema, em 1912, e, em 1926, uma comunicação sobre o "volume das vértebras" dos fueguinos (apresentado no Congresso Internacional dos Americanistas, em Roma) - estudos conduzidos sobre peças conservadas no Museu de Antropologia de Roma que também havia sido fundado por seu pai. Sergi se casou com a irmã de Giuseppe Genna (1896-1988), outro médico e antropólogo ligado ao Instituto e à Cátedra de Antropologia de Roma. Também no seu caso, a produção "americanista" é ínfima e ligada a aspectos fisiológicos: há registros da sua participação nas XXI e XXIV reuniões da "Società Italiana per il Progresso dela Scienza” (em 1932 e 1935, em Roma e Palermo, respectivamente), com trabalhos como "A clavícula dos Fueguinos", "A bacia dos Fueguinos", "A forma da orelha em algumas populações americanas". Além disso, o seu nome também comparece como autor de um artigo dedicado aos aspectos “antropológicos” dos judeus ("Gli ebrei come razza”) na revista La difesa della

\footnotetext{
54 Desde 1937, mudaria sua denominação para "Istituto Italiano di Antropologia", que ainda funciona, sediado no Departamento de Biologia Animal e do Homem da Universidade de Roma, embora independente dele. Cf. http://www.isita-org.com/isita/index.htm. Acesso em 30 de abril de 2019. Alliegro (2011, p. 60-80) contextualiza a criação da S.R.A. como uma "cisão" na antropologia italiana de final de Oitocentos, determinando a ruptura com o grupo florentino de Paolo Mantegazza que se localizava na Società Italiana di Antropologia e Etnologia.

55 Sergio Sergi é um nome ainda hoje lembrado na paletnologia ou arqueologia pré-histórica, tendo sido responsável, no final dos anos trinta, por relevantíssimos achados paleoantropológicos que tem permitido reescrever a trajetória dos homens neandertalianos na Europa. Cf. Manzi (2017). Nesse sentido ele é também o autor dos verbetes "Antropologia" (1948) e "Paleoantropologia" (1961), na Enciclopedia Italiana.
} 
razza. Genna, que foi docente de Antropologia em várias universidades italianas (Bari, Florença e Roma), se dedicou a um tema muito distante da América, o estudo das ossadas dos membros da antiga família florentina dos Medici (Lippi, 2006). O terceiro nome que deve aparecer neste parágrafo é o de Giovanni Marro (1875-1952), médico e antropólogo piemontês, filho de um colaborador de Cesare Lombroso (Rabino Massa, 2008). Marro, que em 1926 foi responsável pela criação do Museu de Antropologia e Etnografia de Turim, acabou se envolvendo pesadamente, a partir do final dos anos Trinta, nos debates raciais e racistas italianos, em frequente e dura polêmica com os dois Sergi e com Genna que defenderam, em várias oportunidades, uma “origem africana” para a “estirpe mediterrânea” (Cassata, 2008, Pizzato, 2012), sobretudo no seu livro Primato della razza italiana (1940), sendo, nessa questão, um aliado de Cipriani. Seja como for, a produção científica de Marro é particularmente relevante sobre a antropologia (craniologia, aliás) egípcia, sendo completamente ausente quaisquer contribuição americanista (Rabino Massa, 2008), o que, mais uma vez, lança questionamentos sobre a inclusão dele (e dos demais deste subgrupo) nas listas que estamos considerando.

Numa situação semelhante encontra-se Gioacchino Sera (1878-1960), médico nascido e formado em Roma. Toda a sua carreira científica desenvolvese nas universidades de Florença, Pavia, Milão e Nápoles, sempre assumindo a docência na área de antropologia física e de paleoantropologia (Chiarelli, 2016). É também colaborador da Enciclopedia Italiana, sendo, aliás, o responsável pela seção de "Antropologia" e assinando mais de cinquenta verbetes, entre os quais "Homem", "Paolo Mantegazza", "Origem do Homem", "Paleoantropologia". É interessante notar que o verbete "Raça", também de sua autoria, publicado em 1935, ou seja, três anos antes do Manifesto, configura um entendimento bem diferente do dos seus colegas mais alinhados ao fascismo: “[...] não existe, portanto, uma raça, mas apenas um povo e uma nação italiana. Não existe uma raça né uma nação judia, mas um povo judeu; não existe - erro mais grave de todos - uma raça ariana [...], mas tão somente

\footnotetext{
56 Outras seções também foram coordenadas por personagens da nossa história: Almagià (geografia), Biasutti (Geografia e Etnologia), De Filippi (Viagens e explorações), Pettazzoni (história das religiões) e Arturo Farinelli (Letras germânicas). Estes e mais cerca de sessenta nomes proeminentes da ciência e da cultura italianas, coordenando outras tentas seções temáticas, formaram, em 1925, o "Comitê Técnico" encarregado do planejamento da obra.
} 
uma civilização e uma língua arianas [...] (apud Alliegro, 2011, p. 267, tradução minha). O mais relevante dos seus trabalhos americanistas é "L'altezza del cranio in America. Induzioni antropologiche ed antropogeografiche"57, um estudo craniológico comparativo com mais de 250 páginas publicado no mantegazziano Archivio per l'Antropologia e l'Etnografia, em 1912, e resenhado e elogiado, no Journal da $S A P$, por Paul Rivet. Mesmo assim, é lembrado muito mais para os seus trabalhos de morfologia comparada dos primatas do que para a sua contribuição à americanística.

É muito diferente a trajetória de Antonio Mordini (1904-1975), que se formou em arqueologia e etnologia na universidade de Florença, onde foi aluno, entre outros, de Almagià e Biasutti. Os seus interesses iniciais foram eminentemente americanos: em 1926 iniciou uma série de viagens que o levaram à Amazônia (na Guiana Francesa e no Brasil ${ }^{58}$ ), onde desenvolveu pesquisas nas regiões dos rios Oiapoque e Jari e na Ilha do Marajó. Em várias oportunidades estabeleceu parcerias com o etnólogo teuto-brasileiro Curt Nimuendajú, com quem teve também intensa troca de correspondência, até meados dos anos trinta (Welper, 2002). Sua contribuição é relevante por estudiosos da cerâmica marajoara (Palmatary, 1949), tendo publicado ao menos dois trabalhos muito citados sobre esse tema ${ }^{59}$. Em seguida, seus interesses se voltaram para a África, especialmente para as colônias italianas e, sobretudo, Etiópia e Somália, onde desempenhou, também, papéis oficiais em nome do governo italiano. Mesmo assim, e diferentemente de muitos dos autores aqui abordados, sua relevância para a americanística italiana é muito significativa. Além da sua colaboração com Nimuendajú e das suas publicações oriundas das suas primeiras viagens à América, Mordini foi secretário da seção de arqueologia da América do Sul no XXIV Congresso Internacional dos Americanistas (em Hamburgo, 1930, quando apresentou um trabalho sobre "Les cultures précolombiennes du Bas Amazone et leur développement

57 Parcialmente disponível em http://www.bibvirtual.ucb.edu.bo/etnias/digital/106002160.pdf. Acesso em 7 de maio de 2019.

58 Tendo explorado a divisória de águas entre o território francês e o Brasil, publicou, em 1931, "Lo spartiacque guiano-brasiliano", no Bollettino da Sociedade Geográfica Italiana.

59 "I 'couvre-sexe' precolombiani in argilla dell'isola di Marajo", no Archivio per l'Anthropologia e l'Etnologia, Firenze 50, 1929, p. 41-46; e "Les cultures precolombiennes du bas Amazone et leur developpement artistique", apresentado no XXIV Congresso Internacional dos Americanistas (1930). 
artistique"), diretor da seção de arqueologia americana do Museu Nacional de Antropologia e Etnologia de Florença e, em 1935, diretor da revista America, do CISA $^{60}$, e membro correspondente do Institut Français d'Etudes Andines (Ricci, $1977^{61}$ ). Além disso, são de sua autoria cerca de 25 verbetes de assunto americano na Enciclopedia Italiana, entre os quais "Mundrucu" [sic], "Maya", "Parintintin", "Palenque, "Sambaqui", "Marajó", quase todos de interesse arqueológico.

É também um estudioso de arqueologia, porém "diletante", o médico Giuseppe Mazzini $^{62}$ (1878-1953). Formado em Medicina na Universidade de Bolonha, em 1899, quatro anos depois emigra para o Chile, onde ficaria até 1911, exercitando a profissão. Depois de um biênio na Itália, em 1913 voltou à América do Sul, passando mais oito anos, entre Equador e Peru (Guarnotta, 1992). Foi nesses dois longos períodos que ele desenvolveu interesse pelas culturas pré-colombianas, concentrando-se na produção cerâmica, se tornando inclusive um apaixonado colecionista. Essa vertente beneficia-se de um fato "geo-cultural": a cidade onde Mazzini nasceu, Imola, encontra-se a cerca de 15 $\mathrm{km}$ de distância de Faenza, o maior centro de produção cerâmica no país, desde a época romana, e que abriga um grande "Museu Internacional das Cerâmicas", fundado em 1908. Essa instituição sediou cursos de história da cerâmica, de alguns dos quais se encarregou Mazzini, juntamente com outras personagens da nossa história, como Mordini e o próprio Callegari ${ }^{63}$, focalizando nas suas aulas a produção incaica e a "aborígene" do Chile (ibidem). Nessa perspectiva e com esses conhecimentos específicos, ele participou de outras instâncias do campo da americanística: foi admitido como membro titular da SAP em 1931e, como vimos, foi também sócio do CISA tendo participado do seu Comitê de Etnografia Americana. Em 1937 doou ao Museu de Faenza a sua coleção, que era composta de 75 peças, incluindo objetos de bronze e tecidos (Guarnotta, 1987). É também significativa a obra

$60 \mathrm{O}$ projeto da revista acabou não se concretizando (Gandini, 2002, p. 237).

${ }^{61} \mathrm{O}$ autor desse necrológio, Lanfranco Ricci (ele mesmo um arqueólogo e linguista especialista em Etiópia), reproduz, sem referência, o texto de um currículo redigido pelo próprio Mordini.

62 Mazzini acrescentou o sobrenome materno "Cita", para se distinguir de um ilustre político italiano da época do Risorgimento.

63 Os cursos eram na realidade promovidos pelo "Istituto Interuniversitario Italiano", fundado em 1923 por Giovanni Gentile (à época ministro da Educação do governo Mussolini) e que tinha por missão a divulgação da cultura italiana no exterior e entre os estrangeiros residentes na Itália (Cavarocchi, 2010). 
americanística de Mazzini, que compreende cerca de 30 estudos e conferências, entre 1928 e 1949, contemplando temas arqueológicos e etnográficos, sendo que pelo menos dez textos têm por assunto a medicina popular andina, ou as formas e os conhecimentos terapêuticos das populações pré-colombianas e indígenas das regiões que ele percorreu, articulando assim os seus interesses americanistas com a sua profissão médica (ibidem). Dessa forma, é possível afirmar que a figura de Mazzini se coloca a meio caminho entre as várias "configurações" de intelectuais americanistas vistas até aqui, sendo aquele que deixou mais próximos os seus interesses de pesquisador e de colecionista com a sua profissão e com a realização de longas viagens à América do Sul. Por outro lado, essa proximidade comporta, paralelamente, uma separação entre esse núcleo de interesses intelectuais e as atividades de docência universitária. De forma análoga a Maria Savi-Lopez e a Antonio Mordini (que, porém, como servidor do Estado italiano desenvolveu intensíssimas atividades de pesquisa “oficial”), Mazzini é um dos pouquíssimos entre as personagens aqui selecionadas a não ter se dedicado em tempo integral ao ensino superior.

Os próximos quatro nomes, que encerram agora a galeria de "americanistas" presentes em uma ou mais das três listas consideradas (Riccardi, Boccassino, Corso e Pettazzoni), destacam-se dos demais por dois critérios em comum. Em primeiro lugar porque se trata de estudiosos que se dedicaram principalmente à docência universitária e, mais do que isso, fizeram da instituição acadêmica a sede para as suas atividades intelectuais, incluindo nessa esfera formas relativamente novas de exercício do "poder" simbólico, que lhes garantiu acesso privilegiado a espaços e recursos nacionais e internacionais e isso, algo paradoxalmente, antes, durante e depois da vigência do regime autoritário italiano chefiado por Benito Mussolini. O segundo elemento que eles compartilham deriva deste primeiro, e é o fato de que, nessas posições, e de forma mais orgânica do que ocorreu com alguns dos mais velhos (como Mantegazza, Giglioli, Mochi ou Sergi), articularam a construção de "linhagens", através da formação de alunos e discípulos e do acompanhamento e do favorecimento (em alguns casos) das suas carreiras - o que também incluiu modalidades mais "modernas" de participação nos conflitos e nas controvérsias institucionais. Nesse sentido, inclusive, a sua 
atuação e a sua influência (política e teórica) se projeta até os dias de hoje, considerando que foi fundamentalmente através dessas linhagens que vieram se formando os quadros epistemológicos contemporâneos tanto das ciências etno-demo-antropológicas quanto, em dimensão menor, da própria americanística contemporânea, nas universidades italianas ${ }^{64}$. Além dessas duas características, também vale adiantar aqui que se trata de nomes que pouco ou nada fizeram para serem considerados "americanistas", como agora veremos mais de perto.

O geógrafo Riccardo Riccardi (1897-1981), que foi aluno de Almagià em Roma, foi professor de Geografia em Catania e, desde 1939, na universidade de Roma. Foi também sócio do Instituto Italiano de Antropologia, mas a sua produção bibliográfica foi essencialmente de cunho geográfico, tendo publicado, ao longo da vida, ao menos quatro grandes livros de geografia americana: Ecuador: naturali ed economiche, cenni storici $e$ culturali (1925), L'America settentrionale (1934), L'America meridionale in generale, gli stati andini, le Guiane, il Paraguay, l'Argentina, l'Uruguay (1938), L'America meridionale: lineamenti geografici (1950) e redator de mais de 120 verbetes para a Enciclopedia Italiana abordando aspectos geográficos das Américas. Logo depois do final da II Guerra Mundial e, portanto, no começo dos processos de redemocratização da sociedade e das universidades italianas, esteve no grupo de promotores de um "Instituto para as Civilizações Primitivas", na Faculdade de Letras e Filosofia da Universidade de Roma, sob a batuta de Raffaele Pettazzoni, que contou também com a participação de Almagià, Sergi, entre outros, e de dois jovens etnólogos que se preparavam para construir uma nova fase da história dos estudos antropológicos na Itália: Vinigi Grottanelli e Ernesto De Martino (Gandini, 2004b, p. 124). O Instituto teria um acentuado caráter "etnológico", e abrigaria uma "Escola de Aperfeiçoamento" em "Civilizações Primitivas" (ou Etnologia"). Nela, as áreas contempladas seriam Etnologia, Etnografia (nesse momento considerada como uma subárea da museografia), Linguística geral, Religiões dos Povos Primitivos, "Sociologia e Economia dos Povos Primitivos, Antropogeografia, Antropologia (ou seja, a física), Paletnologia, Psicologia dos Povos Primitivos, incluindo disciplinas

${ }^{64}$ Só para exemplificar, talvez valha dizer que eu mesmo, que terminei o curso de Antropologia na Universidade de Roma, fui aluno de um aluno de Raffaele Pettazzoni. 
“especiais" de "Instituições e religiões primitivas da África", "Civilizações Primitivas da América", "Civilizações Primitivas da Ásia e da Oceania” (ibidem, p. 125) ${ }^{65}$. A partir daí, Riccardi, como membro da Congregação da Faculdade, participa de todas as atividades com que esta busca se reestruturar, dando vida a novas regras acadêmicas e, sobretudo, a novos institutos e cátedras, que incluirão, muito em breve, também o ensino de alguns aspectos do que já não se chamaria mais, pelo menos oficialmente, americanistica.

É muito diferente o caso de um colega mais jovem Renato Boccassino (1904-1976) ${ }^{66}$. Nascido no Piemonte, transferiu-se para Roma, onde, em 1926, se formou em Letras com um trabalho sobre religiões de populações aborígenes da Austrália, orientado por Raffaele Pettazzoni. Este, depois da diplomação, incentivou o seu aluno a se aperfeiçoar no exterior: assim, Boccassino esteve em Paris, onde frequentou os cursos de Paul Rivet, Marcel Mauss e Lucien Lévi-Bruhl, e em Viena, onde estudou com o padre Wilhelm Schmidt. Em 1931, novamente graças a Pettazzoni, conseguiu uma bolsa para estudar em Londres com Malinowski e Seligman e, em seguida, desenvolver pesquisas de campo na Uganda, onde permaneceu cerca de um ano, entre 1933 e 1934. A partir daí, construiu uma sólida reputação de "africanista", mas, devido às suas escolhas teórico-metodológicas, influenciadas pelo método histórico-cultural incorporado na sua passagem por Viena, iria se posicionar no campo dos "adversários" do seu antigo mestre. Isso determina a sua aproximação das orientações católicas, com o apoio do Vaticano ${ }^{67}$, o que, no clima político do pós-guerra, também vai afastá-lo das primeiras orientações marxistas da geração mais jovem, que começavam a se firmar nas ciências sociais italianas. Apesar disso, ocupou cargos importantes, como o de Diretor do Museu Pigorini (1949-1953) e, desde 1953, a docência de Etnografia na Universidade de Nápoles. Na compilação das publicações de Boccassino

\footnotetext{
${ }^{65} \mathrm{O}$ nome definitivo da Escola seria, a partir do ano sucessivo, Scuola di perfezionamento in Scienze etnologiche (Gandini, 2004b, p. 135).

66 As informações sobre Boccassino estão principalmente em Coppola (2015).

${ }^{67}$ Entre meados dos anos vinte e meados da década sucessiva, o papa Pio XI fomentou o ingresso do Vaticano no campo "etnológico", com a criação do Museu Missionário Etnológico, com a sua revista, Annali Lateranensi, e de uma cátedra de Etnologia, ocupada justamente por Boccasino (Alliegro, 2011, p. 260). Todos esses empreendimentos tiveram a participação decisiva do padre W. Schimdt, figura principal da corrente que defendia a teoria do monoteísmo primitivo, contra a qual se lançaram Pettazzoni e os seus discípulos. Vale lembrar que entre os colaboradores dessa revista também encontramos o nosso Callegari e, depois da sua conversão ao catolicismo, Evans-Pritchard.
} 
(Coppola, 2015, p. 217-219), constam 40 títulos, quase todos de etnologia religiosa - nenhum de assunto americano, o que, mais uma vez, obriga a pensar que a sua inserção no Comitê de Etnologia Americana do CISA, em 1938, foi ocasionado por considerações que extrapolavam a realidade dos seus estudos, se relacionando mais com o fato de que, nesse ano, Pettazzoni ainda tentava contar com ele para alianças político-acadêmicas. A ruptura definitiva entre Boccassino e Pettazzoni determinou, com toda probabilidade, o fato de o primeiro se transferir para Nápoles, a convite de outro desAFeto de Pettazzoni, Raffaele Corso, também próximo do Vaticano.

Este (1885-1965) é um dos nomes principais da história dos estudos demo-etno-antropológicos italianos no período que estamos explorando. Nascido na Calábria, formado em direito em Nápoles (1906), desenvolveu desde os anos de formação interesse pela cultura popular do sul da Itália, na esteira do pai dessa disciplina, o siciliano Giuseppe Pitrè. Esse pioneirismo de Corso se concretizou sobretudo no âmbito universitário: foi o primeiro a lecionar "Etnografia" na Universidade de Roma (1914-1921) e, a partir de 1922, foi professor desta disciplina na Universidade de Nápoles. Para além das atividades voltadas para o estudo do folclore, teve uma fase de interesses africanistas, sobretudo no período em que isso era incentivado pelo regime fascista. Nunca, porém, se dedicou a temas americanos. Embora fortemente marcado pela proximidade política e ideológica com o regime de Mussolini, Corso continuou até a aposentadoria a desempenhar as suas funções acadêmicas, dotado sempre de rico capital simbólico, capaz de influenciar momentos relevantes da história institucional das ciências sociais italianas, ao longo de mais de cinquenta anos. Assim, a sua presença na lista de “americanistas" italianos, redigida por Callegari em 1946, que é a única em que a princípio não haveria influência de pesos políticos adquiridos, inclusive e sobretudo no recém-concluído período fascista, ainda mereceria algum aprofundamento crítico.

Finalmente, o caso mais emblemático dessa longa galeria de estudiosos: Raffaele Pettazzoni (1883-1959) ${ }^{68}$. Ator de destaque no cenário da vida

${ }^{68}$ É necessário informar logo que à trajetória de Pettazzoni é dedicada a obra impressionante de Mario Gandini: uma "biografia" publicada em trinta "capítulos", na revista Strada Maestra, 
intelectual italiana em boa parte do século XX, desde um lugar temático objetivamente pouco propício para essa liderança - a história e a etnologia das religiões - Pettazzoni nunca foi um "americanista", propriamente dito, mas, sob vários aspectos, se deve a ele a configuração que a americanística italiana assumiu no século passado. Posicionado em vários lugares institucionais ao longo da sua trajetória, capaz de passar incólume pelo regime fascista (nem aderindo à sua ideologia nem sendo perseguido por ele), se tornou uma personalidade científica de repercussão nacional e internacional (Puccini e Squillacciotti, 1979, p. 71 e sg.) e, apesar de o seu nome estar fixado no campo da religião, ele aparece em numerosas passagens e inflexões que determinaram a evolução do campo etno-antropológico, justamente, aliás, nos momentos decisivos pelos quais passou o processo de criação da moderna antropologia cultural italiana, inclusive no seu esforço de libertação das heranças "antropológicas" do século XIX e, mais ainda, da época fascista, com o seu contexto africanista e colonial que já observamos. Ativo (com centenas de publicações, conferências e participações em congressos na Itália e no exterior) desde os anos 1910, tendo concluído o seu curso de Letras clássicas em 1905, em Bolonha, foi adquirindo capital simbólico em medida cada vez maior, até ocupar, em 1924, por concurso, a primeira cátedra italiana de História das Religiões, na universidade de Roma. A partir desse momento, até o final da sua vida, portanto durante mais de trinta anos, Pettazzoni estará presente em inúmeras oportunidades onde a temática (política, institucional, geográfica, histórica, etnológica, antropológica, linguística e, claro, religiosa) também será "americana" ou "americanista". Assim, ao menos no seu caso, o fato de ele não ter sido um americanista é amplamente compensado pela sua posição num campo maior - o das ciências humanas e sociais italianas ${ }^{69}$, o que nenhum dos

de 1989 a 2009, perfazendo cerca de 5 mil páginas. Na realidade, uma reconstrução, fartissimamente documentada, de uma fase inteira da vida intelectual italiana (e de algumas das suas relações internacionais). Nela, encontram-se dezenas de referências e informações relativas aos personagens que protagonizam este trabalho. Tudo isso, com o acréscimo de numerosos outros materiais (fotografias, correspondências, índices, links etc.) está disponível em http://www.raffaelepettazzoni.it/.

69 Alliegro (2011, p. 16 e 251 e sg.) é um dos autores que defendem a ideia de que coube a Pettazzoni a verdadeira "fundação" do campo etno-antropológico italiano, graças à separação que ele promoveu, entre "abordagens físico-anatômicos" e "histórico-culturais". A mesma posição seria assumida, a partir dos anos cinquenta, por discípulos diretos e indiretos do próprio Pettazzoni, como Ernesto De Martino e Tullio Tentori, eles, sim, inseridos a pleno título no rol dos antropólogos culturais italianos. 
demais personagens aqui abordados conseguiu. Insere-se nesse quadro o fato de que, em 1937, ele também assume a titularidade da cátedra de Etnologia, na mesma universidade.

Segundo Gandini (1994, p. 190), que organizou e estudou o arquivo pessoal de Pettazzoni, as primeiras leituras de assunto americanas passam pelo seu interesse principal nas religiões, mas, começadas por volta de 1909, são até mesmo anteriores às relativas a outras regiões do mundo. $\mathrm{O}$ autor (ibidem, p. 191), com base em elementos "micro-filológicos") constrói uma hipótese de cronograma de leituras, no qual aparecem:

África; África (interesse religioso); Ibéricos, Bascos, África do Norte; Oceania-interesse religioso; Oceania e Malásia (etnografia); Indonésia (Malásia); Malésia-Indonésia (interesse religioso); Polinésia, Ilha de Páscoa - Etnografia; América em geral; Antigas civilizações americanas; América do Norte em geral; América do Norte (etnografia); América do Norte (religião); América Central; América do Sul em geral; Peru; Esquimós e Povos Polares; Bibliografia das religiões da Índia [...] [tradução minha]

Nos anos sucessivos, preparando um trabalho de cunho comparativo sobre as crenças monoteístas entre os "povos primitivos", Pettazzoni compila dezenas de fichas de bibliografia de etnologia americana, em italiano, alemão, francês e inglês, reunidas sob o título "Antiche civiltà americane" (Gandini, 1996, p. 143), incluindo textos inéditos de viajantes e exploradores italianos, conservados no Museu Pigorini de Roma, onde trabalhara de 1909 a 1914. À medida que os seus interesse se deslocam para outros aspectos das religiosidades de interesse etno-antropológico, essa estratégia irá se repetir: Pettazzoni busca e consegue acesso, através de bibliotecas e compras pessoais, a uma grande quantidade de literatura especialista, de várias épocas e países, que ele ficha, elabora e reelabora para os seus estudos eminentemente comparativos - e o horizonte americano está sempre presente, nas leituras e nos textos de sua autoria. Um deles tem também um significado inaugural: em 1926 participa pela primeira vez de um Congresso Internacional de 
Americanistas (o XXII, em Roma), com um trabalho intitulado "La confessione dei peccati nelle antiche religioni americane"70.

Enquanto isso, tendo sido o fundador da revista Studi e Materiali di Storia delle Religioni (em 1925, "órgão" da cátedra que ele passara a chefiar desde o ano anterior ${ }^{71}$ ), nesse periódico publica e encomenda, como diretor, muitos trabalhos também de tema americano. Em 1930, resenhando um livro de Callegari (Introduqione allo studio delle antichità americane), declara que "seria desejável que os esforços de Callegari e de poucos outros estudiosos, voltados a suscitarem na Itália um sério interesse pelos estudos americanistas, fossem apoiados" (apud Gandini, 2000b, p. 197 - tradução minha). Reciprocamente, Callegari, quando publica em 1933 num jornal um artigo intitulado "Americanistica", menciona o colega entre os estudiosos que se ocuparam dessa temática, tendo sido Pettazzoni "autor de um douto e interessante volume sobre a confissão entre os índios da América, que um excelente ensaio de história e filosofia das religiões" (apud Gandini, 2001b, p. 111). É nesse contexto, também, que o nosso autor, circulando por numerosos eventos científicos europeus, em anos em que isso ainda era possível, conhece, frequenta e se relaciona com colegas americanistas alemães, britânicos, americanos, franceses etc. É no meio desse período, em 1935, que em Turim se procede à criação do Centro Italiano de Studi Americani (CISA), como vimos.

É muito interessante a informação (Gandini, 2002, p. 236) pela qual Pettazzoni não participa do I Simpósio do CISA, em outubro de 1936, sobre o qual já falamos e de que destacamos o aproveitamento político por parte do regime, justamente por não querer ligar o seu nome a um empreendimento marcado pelo regime. Entretanto, quando poucos dias depois do encerramento do evento, Almagià e Mordini tentam promover a criação de uma revista do Centro - America - e convidam Pettazzoni a participar do comitê editorial, ele aceita (ibidem, p. 237). Assim como aceitará, em janeiro de 1938, a presidência do Comitê de Etnografia Americana do CISA, que manterá até 1943. Nessa condição, preocupa-se sobretudo de incrementar o acervo bibliográfico do

\footnotetext{
70 Ao tema da confissão dos pecados nas várias religiões e regiões do mundo Pettazzoni se dedicou durante cerca de dez anos, a partir de 1926, publicando dezenas de textos "particulares", reunidos em 3 volumes publicados entre 1936 e 1939, perfazendo mais de mil página de estudos monográficos e comparativos.

71 As edições entre 1925 e 1975 estão disponíveis on line: http://cisadu2.let.uniroma1.it/smsr/
} 
Centro, propondo assinaturas a revistas internacionais, preparando listas de livros a serem adquiridos, além de coordenar as avaliações dos trabalhos a serem publicados pelo CISA (Gandini, 2003a, p. 147). Nesse período, imediatamente sucessivo ao início das suas atividades docentes na cátedra de Etnologia, em Roma, é muito frequente que ele se declare favorável à criação das cátedras de "Americanistica" e de "Civiltà dell'America Precolombiana" (ibidem). Entretanto, o clima antiamericano acentuado por causa do conflito mundial fez com que essas propostas só se concretizassem no pós-guerra (Gandini, 2004a, p. 138).

Paralelamente, Pettazzoni prossegue a sua atividade de ensino e orientação e, ainda nesses anos trinta começam a aparecer alunos que se tornariam discípulos e, em seguida, protagonistas da americanística italiana do pós-guerra. Entre eles, Tullio Tentori (1920-2003) que, frequentando a Faculdade de Letras, em Roma, entre 1938 e 1942, também se dedicará, como voluntário, à reorganização das coleções americanística no Museu Pigorini (Gandini, 2003b, p. 134). Depois de formado, será assistente voluntário de Pettazzoni nas duas cátedras, dando início, então, a uma bem-sucedida carreira acadêmica que o transformará em um dos protagonistas da "nova" americanística italiana, a partir dos anos Cinquenta, e, mais a inda, da introdução da Antropologia Cultural na Itália ${ }^{72}$. Mas isso nos levaria a uma fase que este trabalho não pode nem pretende abarcar.

Embora a trajetória de Pettazzoni ainda compreenda muitas aproximações intelectuais (etnológicas, mas não só), será na sua bibliografia que se encontra a sua contribuição mais significativa. Graças, ainda, ao trabalho de Gandini (2009, p. 179 e sg.), podemos ter acesso a uma listagem de cerca de 570 trabalhos, incluindo livros, artigos, resenhas, notas bibliográficas, trabalhos em anais de congressos e simpósios etc., e excluindo a literatura "nãocientífica" e artigos na imprensa. Destes, há vinte e cinco (entre resenhas, notas bibliográficas, apresentações em congressos e seções de obras maiores, de

\footnotetext{
72 Sobre Tentori, veja Mariotti (2007). Vale acrescentar que Tentori voltou ao Pigorini em 1946 e lá permaneceu até 1955, sempre cuidando das coleções americanas. Também participou dos Congressos dos Americanistas em Nova Iorque (1949) e Cambridge (1952). Em 1970 será, na Universidade de Trento, o primeiro catedrático de Antropologia Cultural do país. Por incentivo de Pettazzoni, Tentori desenvolveu muitos cursos de pós-graduação nos Estados Unidos, levando a a marca da antropologia norte-americana para a Italia. Como nota acertadamente Alliegro (2011, p. 535), Tentori partiu para os Estados Unidos "etnólogo americanista" e voltou "antropólogo cultural".
} 
cunho comparativo), cujos títulos explicitam serem dedicadas a assuntos americanos. É claro que há numerosíssimas outras obras, de caráter geral, em que há menções a aspectos "americanos" de questões e temáticas gerais como, por exemplo, em verbetes para a Enciclopedia Italiana ("Animismo", "Antropomorfismo", "Penitenza" etc.).

\section{Conclusões Finais}

Serão o fim da guerra e o lento processo de reorganização e redemocratização da sociedade italiana (que acarreta transformações, embora, também, lentas, na sua universidade, tanto do ponto de vista organizativo e estrutural, como nos aspectos políticos, teóricos e filosóficos) a determinarem, a partir de 1946, a abertura de um novo ciclo para a americanística italiana. O que foi exposto até aqui permite afirmar, na minha leitura, que o panorama que se abriu é muito independente do ciclo anterior, com a exceção da atuação dos jovens estudiosos que passaram, direta ou indiretamente, por Pettazzoni. Os interesses "americanos" na Academia italiana, no período que consideramos, foram escassos e pouco consistentes.

$\mathrm{Na}$ maioria das vezes em que eles apareceram, estiveram atrelados (e, mais do que isso: subordinados) a outros campos do saber, como, principalmente, a antropologia física. Aquilo que um pioneiro (mas não necessariamente um "pai fundador", como vimos) como Callegari considerava a base da americanística (o estudo das civilizações pré-colombianas) despertou poucos adeptos, nas décadas aqui consideradas. Nem a arqueologia nem a linguística nem a etnologia olharam para a Américas com o mesmo interesse com que olharam para outros lugares do mundo. Por um lado (e isso valeu sobretudo para a arqueologia, mas a partir do final do século XIX também para aquela modalidade da etnologia que se voltava para o "folclore" ${ }^{\text {73 }}$ ), o clima filosófico, político e epistemológico da Itália pós-unitária enxergava no próprio território nacional o terreno prioritário para as grandes campanhas de estudo. Por outro, os interesses coloniais italianos (e o seu contexto ideológico) levaram, inclusive graças a incentivos de vária natureza, muitos "cientistas" para a África, de forma que, de fato, se pôde observar uma "etnografia

\footnotetext{
${ }^{73}$ Sobre isso, cf. Lombardi Satriani, 1975.
} 
colonial” (Alliegro, 2011, p. 209 e sg.) ${ }^{74}$, em convívio (raramente em conflito) com os processos de institucionalização acadêmica das ciências sociais do país. Finalmente, creio que seja possível considerar, como causa concomitante para essa escassez e para essa pouca consistência, o fato de que uma outra parcela da vida intelectual italiana, ampla e muito relevante, por estar atrelada a uma tradição capaz de mobilizar recursos retóricos e narrativos poderosos, e que, para sintetizar, ainda que grosseiramente, definirei "clássica", não conseguiu e/ou não teve interesse em voltar seus investimentos epistemológicos para um continente que (com a exceção daquilo que se relacionava aos navegantes italianos), devia ainda evocar horizontes excessivamente "primitivos". Apesar dos esforços de uma Savi Lopez, de um Mordini, de um Mazzini e, sobretudo, de um Callegari, o termo civiltà ainda era flexionado em perspectiva europeia, na Itália.

Assim, é fácil agora compreender o escassíssimo peso que a americanística italiana teve no resto da Europa e nas próprias Américas. Dos dezessete nomes aqui destacados, apenas Callegari e Pettazzoni (e por outros motivos) tiveram, como americanistas algum tipo de repercussão intelectual fora da Itália. Muito diferente foi o prestígio de alguns americanistas franceses - por óbvio - mas, também, alemães, britânicos, suecos, holandeses e, claro, norteamericanos $^{75}$. Paradoxalmente, foi de certa forma oposta a repercussão de uma outra categoria de "americanistas" italianos que, porém, ainda que com poucas excepções, não foram reconhecidos, na Itália, como americanistas. Refiro-me aos que se destacaram como viajantes e/ou "aventureiros". Como observa Christino (2007, p. 57-58),

A nítida distinção entre aventureiros e sul-americanistas [...] permite notar que chefiar uma expedição não garantia a ninguém o direito de ser encaixado na segunda categoria. [...]

\footnotetext{
74 À margem da nossa investigação, encontram-se, no período que corresponde ao regime mussoliniano, empreendimentos significativos, como a criação da "Società Africana d'Italia", das cátedras de "Etiopistica", de "Bérbero", de "Etnografia Africana", a organização de "Congressos Coloniais", além do fomento a pesquisas conduzidas no continente africano (cf. Alliegro, 2011, p. 209-228).

75 Christino (2007, p. 39) resume: no período 1890-1929, se configurou uma "comunidade de especialistas realmente engajada em um projeto coletivo e internacional de construção do conhecimento. Na documentação analisada, os laços de cooperação científica de pesquisadores europeus [...] entre si e com colegas sul-americanos [...] surgem com muito mais força do que testemunhos de rivalidades ou de brigas por prestígio". A autora estudou a relação entre os "sul-americanistas" europeus e o historiador brasileiro Capistrano de Abreu.
} 
Ainda que as expedições "sérias" a lugares desconhecidos trouxessem inegável prestígio aos autênticos pesquisadores-viajantes, as viagens não chegavam sequer a constituir uma condição necessária para que um intelectual figurasse no primeiro time da Sul-Americanística dos anos 1890-1929. Isso porque, a forma de tratamento dos dados assumia então, no julgamento da relevância científica de um trabalho, maior peso do que a recolha in loco dos mesmos. Dito de outra maneira, dados de segunda mão tratados com rigor mereciam mais respeito do que dados coletados no campo pelo próprio pesquisador, mas não submetidos a um procedimento julgado confiável de análise.

Nessa perspectiva, seria muito mais extensa e significativa a lista de italianos que, entre meados do século XIX e meados do século XX, em várias circunstâncias, por vários motivos e em condições diferentes, passaram períodos mais ou menos longos em países da América. Limitando-me à América do Sul (e deixando claro que este parágrafo é apenas um lembrete ou um alerta para trabalhos futuros), incluindo médicos, militares, missionários e outros, italianos, que circularam nos e produziram sobre os países da região, e que foram lidos e comentados por lá (e nada ou muito pouco na Itália), valeria citar Gaetano Osculati (1808-1894), Emanuele Castrucci da Vernazza (18131888), Bartolomeo Bossi (1817-1890), Giacomo Bove (1852-1887), Maggiorino Borgatello (1857-1929), Cesare Albisetti (1888-1977) ${ }^{76}$ - mas haveria ao menos mais três dezenas ${ }^{77}$. Talvez os únicos que, mesmo tendo tido biografias e trajetórias mais orientadas para o lado aventureiro do que para o acadêmico, mas, ainda assim, revestiram alguma importância no cenário da americanística, foram Guido Boggianni (1861-1902) e Ermanno Stradelli (1852-1926), protagonistas de longas, repetidas e importantes viagens na América do Sul. Não por acaso, foi ainda Petttazzoni a escrever um texto dedicado à memória do primeiro, em 1941, e a publicar alguns dos mitos amazônicos coletados pelo

\footnotetext{
76 Borgatello, padre salesiano, esteve na Terra do Fogo e participou do XXII Congresso Internacional, em Roma, com um trabalho de linguística indígena (Alakaluf). A ele está intitulado, em Punta Arenas (Chile), o Museu Salesiano Etnográfico.

77 Trata-se do desenvolvimento da parte preponderante do meu projeto de pesquisa mencionado anteriormente. Entre eles há os que, tendo começado suas carreiras com viagens e explorações, se dedicaram, em seguida, a atividades científicas e/ou de divulgação. Um exemplo é Alberto Maria De Agostini (1883-1960), salesiano, que esteve na Patagônia e na Terrra do Fogo entre 1910 e 1945. Participou do Congresso de Roma, em 1926, apresentando o relato "I miei viaggi nella Cordigliera della Terra del Fuoco". Outro salesiano que, apesar de ter pertencido à $S A P$ (desde 1927) e ter participado do Congresso de Roma (onde apresentou um trabalho sobre um aspecto da "bruxaria" Bororo e outro sobre a língua dessa etnia), foi Antonio Tonelli (1877-1938), nunca foi mencionado por Callegari. Tonelli esteve em Mato Grosso, na Patagônia e na Terra do Fogo.
} 
segundo (Gandini, 2009) ${ }^{78}$. Dessa forma, e em face da ainda pequena atenção que algumas dessas trajetórias têm despertado na literatura (tanto italiana quanto latino-americana), e entendendo que essa separação entre americanistas, tout court, e outras trajetórias que permitiriam aumentar o acervo de olhares italianos sobre as alteridades latino-americanas, embora enraizada nos discursos dos contemporâneos, não pode ser endossada pela investigação, remeto a novas investidas e investigações os acréscimos e articulações que se fazem necessários.

\section{Referências bibliográficas}

ABBATTISTA, Guido. Umanità in Mostra. Esposizioni etniche e invenzioni esotiche in Italia (1880-1940). Trieste: Edizioni Università di Trieste, 2013.

AIMI, Antonio. "Mantegazza e la coca: Una ricerca da rivalutare". In: PASINI, Walter; CHIARELLI, Cosimo (orgs.). Paolo Mantegazza e l'evoluzionismo in Italia. Firenze: Firenze University Press, 2010, p. 163-176.

ALLIEGRO, Enzo Vinicio. Antropologia italiana. Storia e storiografia. 1869-1975. Firenze: SEID, 2011.

ARENAS, Patricia. "La antropología en Argentina a fines del siglo XIX e principios del XX”. Runa, v. XIX, 1989-1990, 147-160.

BARBAGLI, Fausto. Enrico Hillyer Giglioli nei suoi rapporti con Paolo Mantegazza e la Società Italiana di Antropologia e Etnologia. Archivio per l'Antropologia e la Etnologia, v. CXLIV, p. 165-176, 2014. Disponível em https://www.academia.edu/27703024/Enrico Hillyer Giglioli nei suoi rapp orti con Paolo Mantegazza e la Societ $\%$ C $3 \% \mathrm{~A} 0$ Italiana di Antropologia e Etnologia. Acesso em: 04 de abril de 2019.

BARBAGLI, Fausto; PRATESI, Giovanni (coord.). Guida alle Serioni del Museo di Storia Naturale dell'Università di Firenze. Firenze: Polistampa, 2009.

BARROS FILHO, Omar et al. Os caminhos de Garibaldi na América. São Paulo: Perspectiva, 2007.

78 Sobre Boggianni, cf. Frič e Fričeva (2001) e Reyero (2012). Sobre Stradelli, cf. Cascudo (1936) e Raponi (2016). 
BRAVO HERRERA, Fernanda Elisa. Racconti di viaggio in Argentina: interpretazioni e proposte di lettura. Problemi di storiografia e conformazione del canone. In: CEBALLOS Aybar, Norma R. (comp.), Lectura y lectores. Córdoba: Anábasis, 2012, p. 95-102. Disponível em https://www.academia.edu/2070300/ Racconti di viaggio in Argentina int erpretazioni e proposte di lettura. Problemi di storiografia letteraria e co nformazione del canone. Acesso em: 04 de abril de 2019).

BRIONES, Claudia. "Con la tradición de todas las generaciones pasadas gravitando sobre la mente de los vivos": usos del pasado e invención de la tradición”, Runa, v. 21, n. 1: p. 99-129, 1994.

CALLEGARI, Bruno Valeriano. "Americanistica". In: Enciclopedia Italiana, vol. II. Roma: Treccani, 1929. Disponível em: http://www.treccani.it/enciclopedia/americanistica \%28EnciclopediaItaliana\%29/ Acesso em: 18 de abril de 2019.

"Un artista dela razza. Pedro Centeno visto da un americanista". A. III, n. 24, 1940, p. 12-15. Disponível em http://www.thuleitalia.net/Storia/DifesaRazzaOttobre24.pdf. Acesso em: 6 de maio de 2019.

CALLEGARI, Bruno Valeriano. Curriculum vitae e pubblicazioni americane di Guido Valeriano Callegari libero docente d'antichità americane 1906-1946. Verona: Scuola Tipografica Don Bosco, 1946. Disponível em https://issuu.com/agostinoconto/docs/autobiografiacallegari. Acesso em: 04 de abril de 2019.

CANADELLI, Elena. La morte di Filippo De Filippi a Hong Kong (1867). Il racconto inedito di un missionario. Atti della Società Italiana di Scienze Naturali e del Museo Civico di Storia Naturale di Milano, v. 153, n. 1, p. 85-110, 2012.

CANDELORO, Giorgio. Storia dell'Italia Moderna. Vol. IV. Dalla Rivoluzione nazionale all'unità (1849-1860), Milano: Feltrinelli, 1964.

Storia dell'Italia Moderna. Vol. V. La costruzione dello Stato unitario (1860-1871), Milano: Feltrinelli, 1968.

Storia dell'Italia Moderna. Vol. VI. Lo sviluppo del capitalismo e del movimento operaio (1871-1896), Milano: Feltrinelli, 1970.

Storia dell'Italia Moderna. Vol. VII. La crisi di fine secolo e l'età giolittiana (1896-1914), Milano: Feltrinelli, 1974. 
CAPITAN [Louis]. "G. V. Callegari: L'Antico Messico [compte-rendu]". Journal de la Société des Americanistes, Tome 5, 1908. pp. 123-124. Disponível em: www.persee.fr/doc/jsa 0037-9174 1908 num 51 3506. Acesso em: 16 de maio de 2019.

CARACI LUZZANA, Ilaria. “Almagià, Roberto”. In: Diæizionario Biografico degli Italiani, vol. $\quad 34, \quad 1988 . \quad$ Disponível em: http://www.treccani.it/enciclopedia/roberto-almagia (DizionarioBiografico)/. Acesso em: 6 de maio de 2019.

CASCUDO, Luís de Câmara. Em memória de Stradelli. 1852-1926. Manaus: Livraria Clássica, $1936 . \quad$ Disponível em: https://issuu.com/bibliovirtualsec/docs/em memoria de stradelli_ 1936. Acesso em: 13 de maio de 2019.

CASSATA, Francesco. "La Difesa della razza". Politica, ideologia e immagine del razzismo fascista. Torino: Einaudi, 2008.

CAVALLO Giacomo Walter. "La metodologia delle indagini antropologiche di Federico Lunardi, il Nunzio dei Maya". Miscellanea di Storia delle esplorazioni, v. XXXVIII, pp. 237-266, 2013.

CAVAROCCHI, Francesca. Avanguardie dello spirito. Il fascismo e la propaganda culturale all'estero. Roma: Carocci, 2010.

CERULLI, Ernesta. "Biasutti, Renato". In: Diæ̌ionario Biografico degli Italiani, vol. 10, 1968. Disponível em: http://www.treccani.it/enciclopedia/renatobiasutti_(Dizionario-Biografico)/. Acesso em: 16 de maio de 2019.

CHIARELLI, Brunetto. La fase acquatica della evolurione umana. Broni: Altervista, 2016.

CHIARELLI, Cosimo; PASINI, Walter (orgs.). Paolo Mantegazza e l'evoluzionismo in Italia. Firenze: Firenze University Press, 2010.

CHIOZZI, Paolo. "Gi album fotografici di Lidio Cipriani". AFT. Rivista di Storia e Fotografia, n. 11, 1990, p. 21-53. Disponível em http://rivista.aft.it/aftriv/controller.jsp?action=rivista browse\&rivista id $=3 \&$ rivista pagina=21\#pag 21. Acesso em: 30 de abril de 2019.

CHRISTINO, Betraiz Protti. A rede de Capistrano de Abreu (1853-1927): uma análise historiográfica do rã-txa bu-ni-ku-ĩ em face da Sul-americanistica dos anos 18901929. Tese. Doutorado em Semiótica e Lingüística Geral. Universidade de São Paulo, 2007. 
CIMINO, Guido. "De Filippi, Filippo". Diæionario Biografico degli Italiani, vol. 33, 1987. Disponível em http://www.treccani.it/enciclopedia/filippo-defilippi (Dizionario-Biografico)/. Acesso em: 16 de maio de 2019.

CIMINO, Guido; LOMBARDO, Giovanni Pietro (orgs.). La nascita delle "scienze umane" nell'Italia post-unitaria. Milano: Franco Angeli, 2014.

COELHO, Anna Carolina de Abreu. Santa-Anna Nery: um propagandista "voluntário" da Amazônia (1883- 1901). 2007. Dissertação. Mestrado em História Social do Amazonas. Universidade Federal do Pará, Belém, 2007.

COMAS, Juan. Cien años de Congresos Internacionales de Americanistas. Ensayo bistórico-crítico y bibliográfico, México: UNAM, 1974.

COPPOLA, Maurizio. "Renato Boccassino. Um profilo biobibliográfico". Voci, a. XII, 2005, p. 213-219. Disponível em: https://www.academia.edu/26916882/Renato Boccassino. Un profilo biobl iografico.pdf. Acesso em: 16 de maio de 2019.

CORRÊA, Mariza. As Ilusões da Liberdade: a Escola Nina Rodrigues e a Antropologia no Brasil. $2^{a}$ ed. rev. Bragança Paulista: Editora da Universidade São Francisco, 2001.

D’ENTRÈVES, Pietro Passerin; LATTANZI, Vito; SHEPHERD, Elizabeth Jane; BARBAGLI, Fausto; VIOLANI, Carlo; CIRUZZI, Sara; CALZOLARI, Silvio. Enrico Hillyer Giglioli: l'uomo, il naturalista, il viaggiatore. L'Universo, n. 5, p. 625-672, 1996.

D’ORTA, Sonia Ferraro. Coleções etnográficas: 17650-1955. In: CUNHA, Manuela Carneiro da (org.). História dos Índios no Brasil. São Paulo: Companhia das Letras, 1992, p. 501-528.

D’ORSI, Angelo. “Gorgolini, Pietro”. In: Diżionario Biografico degli Italiani, 2002. Disponível em: http://www.treccani.it/enciclopedia/pietrogorgolini (Dizionario-Biografico)/. Acesso: em 15 de maio de 2019.

DE LIGUORI, Girolamo. Materialismo inquieto. Vicende dello scientismo in Italia nell'età del positivismo (1868-1911). Bari: Laterza, 1988.

Materialismo e scienze dell'nomo. Il dibattito su scienze e filosofia del secondo Ottocento. Manduria: Lacaita, 1990.

DURSTON, Alan. "Ippolito Galante y la filología quechua en los años 1930 y 1940”. Lexis, v. 38, n. 2, pp. 307-336, 2014. 
ESTEVA-GRILLET, Roldán. "Pedro Centeno Vallenilla: el pintor de la raza". In: SARTOR, Mario (coord.). América Latina y la cultura artística italiana: um balance en el Bicentenario de la Independencia Latinoamericana. Buenos Aires: Instituto Italiano de Cultura, 2011, p. 57-98.

FANESI, Pietro Rinaldo. Garibaldi nelle Americhe. Roma: Gangemi, 2007.

FAY, Cláudia Musaç; CONSTANTINO, Núncia Santoro de (orgs.). Garibaldi, História e literatura: Perspectivas internacionais. Porto Alegre: EDIPUCRS, 2011.

FERNANDES, Antonio Carlos Sequeira; et alii. Trocando espécimens de animais por cabeças-troféu Munduruku: o intercâmbio de Enrico Giglioli com o Museu Nacional na segunda metade do século XIX. Filosofia e História da Biologia, v. 5, n. 1, p. 1-19, 2010.

FRIČ, Pavel; FRIČOVÁ, Yvonna (orgs.). Guido Boggiani Fotógrafo. Lisboa: Museo Nacional de Etnologia, 2001.

FULVI, Fulvio. "Il contributo di Federico Lunardi alla conoscenza degli usi e costumi dei popoli dell'America Latina”. Miscellanea di Storia delle esploražioni, v. IV, pp. 257-277, 1979.

GANDINI, Mario. "Raffaele Pettazzoni nell'anno cruciale 1912. Strada maestra, n. 36-37, 1994, p. 177-298.

"Raffaele Pettazzoni dalla libera docenza nell'Università di Roma all'incarico nell'Ateneo bolognese (1913- 1914)". Strada maestra, n. 40, 1996, p. 63-205.

n. 48, 2000a, p. 81-249.

"Raffaele Pettazzoni negli anni 1928-1929". Strada maestra, . "Raffaele Pettazzoni intorno al 1930". Strada maestra, n. 49, 2000b, p. 141-254.

"Raffaele Pettazzoni nelle spire del fascismo (1931-1933)". Strada maestra, n. 50, 2001a, p. 19-183.

. "Raffaele Pettazzoni dal gennaio 1934 all'estate 1935". Strada maestra, n. 51, 2001b, p. 81-212.

2002, p. 99-268. . "Raffaele Pettazzoni intorno al 1935". Strada maestra, n. 52, . "Raffaele Pettazzoni negli anni 1937-1938". Strada maestra, n. 54, 2003a, p. 53-232. 
n. 55,2003 b, p. $121-271$.

. "Raffaele Pettazzoni negli anni 1939-1940". Strada maestra, . "Raffaele Pettazzoni nei primi anni Quaranta". Strada maestra, n. 56, 2004a, p. 93-279.

. "Raffaele Pettazzoni dall'estate 1943 alla primavera 1946". Strada maestra, n. 57, 2004b, p. 21-199.

2006b, p. 55-246.

. "Raffaele Pettazzoni intorno al 1951". Strada maestra, n. 61,

. "Indice generale - Indice dei nomi di persona. Bibliografia degli scritti”. Strada maestra, n. 66, 2009, p. 1-255.

GARCÍA BOTERO, Héctor. Una historia de nuestros otros. Indígenas, letrados y antropólogos en el estudio de la diferencia cultural en Colombia (1880-1960). Bogotá: Editorial de los Andes, 2010.

GARGANO, Antonio. "Arturo Farinelli e le origini dell'ispanismo italiano". In: L'apporto italiano alla tradizione degli studi ispanici. Atti del Congresso. Napoli: s.ed., 1993, p. 55-70.

GIGLIOLI, Enrico Hillyer. Viaggio intorno al globo della r. pirocorvetta italiana Magenta negli anni 1865-66-67-68 sotto il comando del capitano di fregata V.F. Arminjon: Relazione descrittiva e scientifica, pubblicata sotto gli auspici del Ministero di agricoltura. industria e commercio dal dottore Enrico Hillyer Giglioli. Con una introdurione etnologica di Paolo Mantegazza. Milano: V. Maisner e Compagnia Editori, 1875. Disponível em https://reader.digitalesammlungen.de/en/fs1/object/display/bsb11309121 00005.html. Acesso em 16 de maio de 2019.

GOVONI, Paola. Paolo Mantegazza. In: CLERICUZIO, Antonio e RICCI, Saverio (a cura di). Il contributo italiano alla storia del pensiero. Appendice VIII della Enciclopedia Italiana di Scienze, Lettere ed Arti, vol. IV, Scienze, Roma: Istituto della Enciclopedia Italiana, 2012, pp. 392-396. Disponível em: https://www.academia.edu/7954786/Paolo Mantegazza in Antonio Clericu zio e Saverio Ricci direttori Il contributo italiano alla storia del pensiero. Appendice VIII della Enciclopedia Italiana di Scienze Lettere ed Arti v ol. IV Scienze Roma Istituto della Enciclopedia Italiana pp. 392396.

Acesso em 04 de abril de 2019.

GUARNOTTA, Antonio. "Oggetti precolombiani della collezione Giuseppe Cita Mazzini del Museo Comunale di Imola”. S.l., 1987. Disponível em https://www.academia.edu/34663064/Oggetti precolombiani della collezion e Giuseppe Cita Mazzini del Museo Comunale di Imola. Acesso em 8 de maio de 2019. 
GUERRA, Sara Caumo. Paolo Mantegazza (1831-1910) e a escrita scientifica do Amor. 2015. Dissertação. Mestrado em Antropologia Social. Universidade Federal do Rio Grande do Sul. Porto Alegre, 2015.

LANDUCCI, Giovanni. L'occhio e la mente. Scienze e filosofia nell'Italia del secondo Ottocento. Firenze: Olshki, 1987.

Firenze: Olshki, 1977.

Darwinismo a Firenze. Tra scienza e ideologia (1860-1900).

LAURIÈRE, Christine. Padre fundador de la etnología francesa, americanista apasionado, verdadero colombianista: Paul Rivet, un antropólogo polifacético. In: Carl Henrik Langebaek, Clara Isabel Botero (orgs.). Arqueología y etnología en Colombia. La creación de una tradición cientifica. Bogotá: Uniandes-Ceso, 2009a, pp.219-240.

savante au service de

La Société des Américanistes de Paris: une société

l'américanisme. Journal de la société des américanistes, v. 95, n. 2, p. 93-115, 2009b.

LIPPI, Donatella. Illacrimate sepolture. Curiosità e ricerca scientifica nella storia delle riesumazioni dei Medici. Firenze: Firenze University Press, 2006.

LOMBARDI SATRIANI, Luigi M. "Realtà meridionale e conoscenza demologica. Linee per una storia degli studo demologici dagli anni postunitari alla conquista della Libia”. Problemi del Socialismo, a. XX, n. 16, p. 41-66, 1979.

LORÈ, Michele. Antisemitismo e razzismo ne La difesa dela razza. Soveria Mannelli: Rubbettino, 2008.

MANZI, Giorgio. "Storie italiane". In: -. Ultime notizie sull'evoluzione umana. Bologna: Il Mulino, 2017, p. 171-192.

MARIOTTI, Luciana. "Tentori, Tullio". In: Dizionario Biografico dei Soprintendenti Storici dell'arte (1904-1974). Bologna: Bonomia University Press, 2007, p. 593-603. Disponível também em: http://www.idea.mat.beniculturali.it/museo-civilta-mnatp/la-storia/item/127biografia-di-tullio-tentori. Acesso em: 10 de maio de 2019.

MARTIN, Gabriela. Pré-história do Nordeste do Brasil. $5^{a}$ ed. Recife: Ed. da UFPE, 2008. 
MICHELI, Gianni (org.). Storia d'Italia. Annali. Vol. 3. Scienza e tecnica nella cultura e nella società dal Rinascimento a oggi. Torino: Einaudi, 1980.

MOGGI CECCHI, Jacopo. "La vita e l'opera scientifica di Lidio Cipriani". AFT. Rivista di Storia e Fotografia. N. 11, 1990, p. 11-18. Disponível em http://rivista.aft.it/aftriv/controller.jsp?action=rivista browse\&rivista $\mathrm{id}=3 \mathrm{Q}$ rivista pagina=11\#pag 11. Acesso em: 30 de abril de 2019.

MOGGI CECCHI, Jacopo, e ROSCOE Stanyon (a cura di). Il Museo di Storia Naturale dell'Università degli Studi di Firenze. Volume V. Le collezioni antropologiche ed etnologiche. Firenze: Firenze University Press, 2014.

PALMATARY, Helen C. "The Pottery of Marajó Island, Brazil". Transactions of the American Philosophical Society, v. 39, n. 3, p. 261-470, 1949.

PASQUALI, Daniele. Guido Valeriano Callegari. Bibliografia e biografia generali. Ebook. S.l.: s. ed., 2014.

"Il gran rifiuto di Callegari", 31 gennaio 2016. Disponível em: http://gvcallegari.blogspot.com/2016/01/?m=0. Acesso em: 15 de abril de 2019.

PERUGI, Rosella. "Quando le italiane arrivarono al Nord; diari delle prime turiste in Scandinavia". Settentrione: Nuova Serie, n. 28. Disponível em https://research.utu.fi/converis/getfile?id=19069534\&portal=true. Acesso em: 8 de maio de 2019.

PETRUCCI, Valeria. As coleções etnográficas brasileiras na Itália. In: RIBEIRO, Berta; MOREIRA NETO, Carlos; HOONAERT, Eduardo; PETRUCCI, Valeria (eds.). A Itália e o Brasil indígena. Rio de Janeiro: Index, 1983, p. 47-55.

PIZZATO, Fedra Alessandra. Corpi e nazione italiana. Gli esordi dell'antropologia e il problema degli antenati barbarici. Dissertação. Mestrado em História. Università degli Studi di Padova, 2012. Disponível em http://tesi.cab.unipd.it/39515/1/Pizzato fedra.pdf. Acesso em: 6 de maio de 2019.

PODGORNY, Irina. De la santidad laica del científico. Florentino Ameghino y el espectáculo de la ciencia en la Argentina moderna”. Entrepasados. Revista de Historia. Ano VI, n. 1-3, 1997, p. 37-62.

PODGORNY, Irina; Blasco, Élida, Farro, Máximo y Martínez, Alejandro. "Carne de mi carne. El museo como identidad de su fundador en los casos del Museo Nacional de Buenos Aires, el Museo de La Plata y el Museo de Luján, 1880-1930". In: Melo Vasconcellos, Camilo; Funari, Pedro Paulo y Carvalho, 
Aline V. (eds.). Museus e construcão de identidades na América Latina. Campinas: Laboratorio de Arqueología Pública, LAP/NEPAM-Unicamp, 2015a, p. 55-66.

PODGORNY, Irina; Farro, Máximo, Martínez, Alejandro y Ballestero, Diego. Caballeros de la noche. Antropología y museos en la Argentina de las últimas décadas del siglo XIX. In: Carreras, Sandra, Carrillo Zeiter, Katja (eds.). Las ciências em la formación de las naciones americanas. Madrid: Iberoamericana; Frankfurt: Vervuert, 2015b, p. 201-228.

PODGORNY, Irina; Lopes, María Margaret. El desierto en una vitrina. Museos e bistoria natural en la Argentina, 1810-1890. Rosario: Prohistoria Ediciones, 2014.

PRÉVOST URKIDI, Nadia. "Historiographie de l'américanisme scientifique français au XIXe siècle: le 'prix Palenque' (1826-1839) ou le choix archcoologique de Jomard". Journal de la Société des Américanistes, v. 95, n. 2. Disponível em http://jsa.revues.org/11019. Acesso em: 2 de maio de 2019.

PUCCINI Sandra; SQUILLACCIOTTI, Massimo. "Per una prima ricostruzione critico-bibliografica degli studo demo-etno-antropologici italiani nel periodo tra le due guerre". Problemi del Socialismo, a. XX, n. 16, 1979, p. 6793.

RABINO MASSA, Emma. "Marro, Giovanni”". In: Diæionario Biografico degli Italiani, vol. 70, 2008. Disponível em http://www.treccani.it/enciclopedia/giovanni-marro (Dizionario-

Biografico)/. Acesso em: 6 de maio de 2019.

RAPONI, Livia (org.). A única vida possivel: Itinerários de Ermanno Stradelli na Amazônia. São Paulo: Unesp, 2016.

REVELLI, Paolo. Terre d'America e archivi d'Italia. Milano: Fratelli Treves, 1926.

REYERO, Alejandra Paola Yanina. "Imagen, objeto y arte: la fotografía de Guido Boggiani”. Íconos, Revista de Ciencias Sociales, n. 42, Quito, enero 2012, pp. 33-49.

RICCI, Lanfranco. "Ricordo di Antonio Mordini". Africa. Rivista Trimestrale Di Studi e Documentazione Dell'Istituto Italiano per l'Africa e l'Oriente, v. 32, n. 1, p. 135138, 1977. Disponível em: www.jstor.org/stable/40758735. Acesso em: 7 de maio de 2019.

RIVET, Paul. "22 Congrès International des Americanistes". Journal de la Société des Americanistes, Tomo 18, 1926, p. 379-380. 
RIVIALE, Pascal. L'américanisme français à la veille de la fondation de la Société des Américanistes. Journal de la Société des Américanistes. Tome 81, 1995. pp. 207-229.

- Manuel Gonzalez de la Rosa sacerdote historiador y arqueologo. Histórica, v. XXI, n. 2, p. 272-292, 1997.

RODRIGUES, Rafael de Oliveira. Da crônica de viagem ao objeto museal: notas sobre uma coleção etnográfica brasileira em Roma. Tese. Doutorado em Antropologia. Universidade Federal de Santa Catarina, 2017.

ROGARI, Sandro. (a cura di), L'Università degli Studi di Firenze fra istituzioni e cultura nel decennale della scomparsa di Giovanni Spadolini: atti del convegno di Studi. Firenze: Firenze University Press, 2005.

ROSA, Juan Justino da. "Historiografia linguística del Río de la Plata: las lenguas indígenas de la Banda Oriental”. Boletín de Filologia, v. 48, n. 2, pp. 131 171, 2013.

RUSSO, Lucio; SANTONI, Emanuela. Ingegni minuti. Una storia della scienza in Italia. Milano: Feltrinelli, 2010.

SCHWARCZ, Lilia Moritz. O Espetáculo das Raças. Cientistas, instituições e questão racial no Brasil. São Paulo: Companhia das Letras, 1993.

SORRENTO, Luigi. "Recensioni" [a dois trabalhos de Maria Savj-Lopeq]. Aevum, a. 2, n. 3, 1928, p. 463-468. Disponível em: https://www.jstor.org/stable/25818332?read-

now=1\&seq=1\#page scan tab contents. Acesso em: 29 de abril de 2019.

STAGNARO, Adriana Alejandrina. "La antropología en la comunidad científica: entre el origen del hombre y la caza de cráneos-trofeo (1870-1910)". Alteridades, v. 3, n. 6, p. 53-65, 1993.

STRAPPINI, Lucia. "Farinelli, Arturo". In: Diæionario Biografico degli Italiani. Roma: Treccani, $1995 . \quad$ Disponível em http://www.treccani.it/enciclopedia/arturo-farinelli (Dizionario-Biografico)/. Acesso em: 17 de abril de 2019.

VÉLEZ, Palmira. La historiografia americanista en España, 1755-1936. Madrid: Iberoamericana; Frankfurt am Maine: Vervuert, 2007.

VILLARI, Lucio. Bella e perduta. L'Italia del Risorgimento. Roma-Bari: Laterza, 2009. 
VIVANTI, Corrado (org). Storia d'Italia. Annali. Vol. 4. Intellettuali e potere. Torino: Einaudi, 1981.

WELPER, Elena Monteiro. Curt Unckel Nimuendaju: um capitulo alemão na tradição etnográfica brasileira. Dissertação. Mestrado em Antropologia Social. Rio de Janeiro: Museu Nacional, 2002. 